\title{
Estimation of Disaggregated Impacts of Education Expansion on Economic Growth in Sub-Saharan Africa
}

\author{
John Bosco Nnyanzi*, Nicholas Kilimani \\ College of Business and Management Sciences, Makerere University, Kampala, Uganda \\ Email: *jbnnyanzi@yahoo.com
}

How to cite this paper: Nnyanzi, J.B. and Kilimani, N. (2018) Estimation of Disaggregated Impacts of Education Expansion on Economic Growth in Sub-Saharan Africa. Modern Economy, 9, 2119-2149. https://doi.org/10.4236/me.2018.912132

Received: October 10, 2018

Accepted: December 15, 2018

Published: December 18, 2018

Copyright $\odot 2018$ by authors and Scientific Research Publishing Inc. This work is licensed under the Creative Commons Attribution International License (CC BY 4.0).

http://creativecommons.org/licenses/by/4.0/

\begin{abstract}
Underpinned by evidence from the theories of endogenous growth which stress the role of human capital accumulation in enhancing growth, this paper investigates the disaggregated impact of school enrolment on economic growth in Sub-Saharan Africa (SSA) for the period 1995-2016. The analysis is based on the augmented Solow, and Mankiw models and employs the Generalized Method of Moments (GMM) technique that takes care of endogeneity in a dynamic panel environment. The results point to a significant but differential impact of educational expansion in facilitating economic performance in the SSA region. Essentially, the growth enhancing impact of education depends on the type of education with secondary education yielding the largest impacts. The gender disaggregated model results show that and secondary school and primary enrolment yield higher growth effects relative to tertiary enrolment. Most interestingly and contrary to existing literature on the gender disaggregated impact of education on growth, the education of girls is seen to yield higher growth effects relative to boys. Based on evidence of the positive impact of girl-child education, policy interventions to support and sustain girl child education in Sub-Saharan Africa ought to be encouraged.
\end{abstract}

\section{Keywords}

Education, Human Capital, Enrolment, Gender, Economic Growth, Sub-Saharan Africa

\section{Introduction and Rationale}

Over the past two decades, the Sub-Saharan African region has experienced rapid economic growth which coincided with the expansion in enrolment at the 
different levels of education. In fact, developing countries have made considerable progress in closing the gap with developed countries in terms of school attainment [1]. Average GDP growth per capita in Sub-Saharan Africa from 2000 to 2010 was about $2.5 \%$, and the primary gross enrolment rate had increased to $100 \%$ in 2010 [2] [3]. According to the theories of endogenous growth via human capital accumulation, these two phenomena are certainly related. The extent of this relationship is however still an empirical question.

Whereas the neoclassical growth theory posits physical capital and labour as the channels through which economic growth could be achieved, the new growth theories contend that human capital accumulation is a fundamental determinant of a nation's economic growth due to the increase in productivity and technological innovation (see e.g., [4] [5] [6]). The main ingredient in the process of human capital is education and training, which in turn impacts growth through the resulting improvements in labour productivity and it may create a number of externalities which altogether, are growth enhancing [7] and [8]. The new evidence therefore shows that investing in education, training and research, and other forms of human capital may help overcome the problem of diminishing returns, thereby endangering the achievement of long-run economic growth. [9] extended the neoclassical model of Solow [10] by incorporating an explicit process of human capital accumulation and demonstrating that when solving the steady-state per capita income level, an augmented Solow growth model, yields a solution that comprises of physical and human capital as the basic determinants of growth [11]. In fact, existing evidence indicates that basic and advanced skills alike are important, particularly for developing countries [12].

Despite these theoretical breakthroughs and progress made in adding to the evidence on the issues under investigation, it is interesting to note that empirical evidence on the role of education in economic growth is to-date still weak and at most ambiguous. There are several explanations for such mixed outcomes. First, a number of studies use crude proxies, such as the average level of education in their analysis [4]. Such an approach is informed by the assumption that an extra year of tertiary education yields the same level of returns as an extra year of primary education. Scientifically and empirically, this is obviously not the case on efficiency grounds with respect to the utilisation of complex capital. Different studies have thus considered the different levels of education for different channels of the economic growth [13]. [14] and [15] note that the investment in the higher education is more important to increase innovation, which is a critical driver of economic growth in the endogenous framework. However, one would rightly argue that the quality of education offered determines the consequential effect of education on growth. It is not a hidden truth that the quality of education offered in SSA leaves a lot to be desired.

Nevertheless, from a micro perspective too, in comparison with their less-educated counterparts, the acquired skills and resulting productivity by educated workers ensure that they are likely to receive higher incomes that would translate into higher life-time earnings and a subsequent reduction in 
inequality and poverty that are particularly rampant in many developing countries [16] [17]. Implicitly, any tendency for a developing economy to reduce public investment in education in a bid to cut fiscal deficits can in turn be an impediment not only to longer-term growth and development but would also dampen efforts aimed at the alleviation of poverty and inequality [18]. However, it is also worth noting that not all education may lead to positive economic outcomes with the caveat that the quality of education is fundamental in increasing the odds of being employed and earning higher wages (through labour productivity) that help push the educated out of poverty or worse living conditions. In fact, [5] argues that the average level of human capital affects a worker's productivity in addition to the effect of her own human capital.

On the other hand, [4] document that the economic growth experience in Asia was linked to investment in primary and secondary levels of education. This finding led [19] to conclude that investment in education matters for those countries which have the lowest level of education. In fact [20] notes that the returns to education in developing countries continue to be positive, but are likely lower on average today than observed in developed economies like the United States. However, [21] in their literature survey of 57 studies on the effect of education on economic growth show that there is substantial publication selection bias toward a positive impact of education on growth. Nonetheless, once the bias was taken into account, the net growth effect of education was not found to be homogeneous across studies, and varied according to among other factors, the differences in how the education variable is measured, and the characteristics of the economy under investigation as well as the model specification. This mixed empirical evidence points to a fundamental fact that depending on the level of human and technological development of an economy, different levels and types of education impose different degrees of influence on a country's growth trajectory. Reviews and critiques of empirical growth modeling have put much attention on the form of the growth model estimated, including the possibility of omitted factors that would bias the results. However, little attention has been given to measurement issues surrounding human capital. This oversight in the analysis and modeling can potentially lead to misleading conclusions.

Besides, comparing human capital across countries based on school attainment is to assume that the schools across diverse countries are imparting the same amount of learning per year in all countries [1]. A second shortcoming with this measurement of human capital is the presumption of schooling as the only source of human capital and skills. However, it is vital to note that there have been a number of intervention in the areas of health and nutrition that equally impact on human capital development. It is why any analysis of the impact of human capital development on growth that omits such aspects may yield in accurate results. Therefore, cognizant of the role of other factors in augmenting the role of human capital on growth, several studies have considered inter alia health issues relative to learning outcomes (e.g. [22] [23] and [24]). Already the World Health Organization (WHO) [25] notes that of the two billion people 
worldwide affected by Hookworm, roundworm, whipworm, and schistosomiasis, the majority is concentrated among school aged children. Hence, health, would qualify to be a barrier to education since as [26] contends, within an individual, health would enhance schooling outcomes just as longevity would incentivize human capital investment.

In light of the above, we include health in our analysis of the impact of education on economic growth using the different levels of education as well the gender of those that receive the education. The inclusion of the gender dimension in the analysis is motivated first, by the vast literature on the link between parental education, particularly the level of a mother's education, and a child's health (see e.g., [27]). Similarly, a strong relationship exists between a mother's educational level and her child's life expectancy. Unequivocal evidence has shown that educated parents, particularly mothers, have better-nourished children who are less likely to die in infancy than the children of uneducated parents. On average, one year of additional schooling for a mother results in a reduction of 9 per 1000 in child or infant mortality [28]. As such, the influence of education on economic growth via gender is can be revealed through the different positive influences which education imposes on its recipients by gender and which in turn impacts on growth [29]. Moreover, as the latter authors indicate, if good health is also linked to higher life expectancy, healthier individuals would have higher incentives to invest in education and training, as the depreciation rate of the skills acquired would be lower. In sum, education exhibits complex dynamic relationships with health. On this basis, as a nuance in our analysis, we consider health as a channel via which education would affect per capita GDP in SSA.

Second, among the Sustainable Development Goals (SDGs) is the provision of inclusive and equitable quality education at all levels, and that all people, irrespective of gender, access life-long learning opportunities that help them to acquire the knowledge and skills needed to exploit opportunities and to participate fully in society. In order to provide evidence on the possibility for the achievement of such a goal, this study takes a gender-disaggregated and level-specific approach to investigate the effects of male and female education, as measured by primary, secondary and tertiary enrolment ratios, on economic growth. This is further motivated by the fact that there are growing efforts by the African economies to expand enrolment ratios through the allocation of more resources to the education sector. As such, evidence of gains from such efforts is of interest to policy makers as an input into the refinement of public policy especially in the education sector related interventions. The Education for All Global Monitoring Report 2013/2014 predicted that it may not be possible until 2111 when all children in SSA would be expected to complete secondary school education if nothing is done to alter the current trend [30]. Intuitively, low levels of secondary school enrollment are likely to continue keeping the poorest countries from improving average levels of education. On the other hand, the importance of tertiary education cannot be overemphasized. For example it is observed critical in promoting labor force participation rates for women. In support of this argu- 
ment, [31] contends that the participation of women in the labor force is not likely to increase with every level of education but improves significantly at tertiary level where it approaches the rate of men.

Table 1 that presents a snapshot of how per capita growth and education have behaved over the last decades in SSA in comparison to MENA countries. On average, while per capita growth was about 2.8 and 4.2 in the SSA and MENA countries respectively for the period under analysis, primary, secondary and tertiary enrollment was respectively $170.3 \%, 61.4 \%$ and $11.3 \%$ in SSA on the one hand, as compared to $193.3 \%, 136.9 \%$ and $46.5 \%$ in MENA countries ${ }^{1}$. It is also clear from the table that while gross primary enrolment increased from $75.7 \%$ in 1995 to $99.6 \%$ in 2013 , secondary and tertiary enrolment is observed to have grown from $24.4 \%$ and $3.8 \%$ in 1995 to $42.8 \%$ and $8.6 \%$ in 2013 respectively. World Bank data also shows that in SSA while net enrollment in primary school was $75 \%$ in 2009 , primary completion rates were $67 \%$ in the same year. Five years before (2004), however, only $60 \%$ of students were able to progress to secondary school but six years later in 2008 net enrollment in secondary school had gone up to $27 \%$ while gross enrollment in tertiary institutions was $6 \%$. Overall, there was a general improvement in enrollment at all levels of schooling. These improvements notwithstanding, the data show that the SSA region is still lagging in terms of human capital investment despite the latter's potential theoretical role in economic performance as previously argued.

A key interesting observation from data is that while primary, secondary and tertiary enrolment registered respective growth rates of about $90 \%, 75 \%$ and $125 \%$ during the period 1995-2014, per capita income growth rates on the other hand was stagnantly at low levels of about $2.8 \%$. It is therefore logical to test the long-held assumption that education is essential for growth. Perhaps the outcome would depend on the type of education-i.e. whether one is considering primary, secondary or tertiary education. While a lot of emphasis has been placed on primary school enrolment, fewer resources have been devoted to secondary school enrolment as well as tertiary levels.

On average however, available statistics indicate that higher growth levels in these latter two types has relatively improved. The gist of the matter, as observed by [32] is that despite the huge sums of government funds allocated to education, developing countries and SSA in particular still lag behind the rest of the world including fellow developing regions. For example, while between 1999 and 2006 enrollment rates in primary school increased from 54 percent to 70 percent in SSA, the East and South Asia witnessed an increase from 75 to 88 percent. Note that although the GDP growth rates increased from -0.43 in 1999 to 3.23 in 2006, the figure reduced to -0.66 in 2009 only to recuperate to still very low levels of 1.14 and 1.63 in 2012 and 2013 respectively for SSA.

The purpose of our study is to examine the potential role of education in economic growth, especially given that existing literature appears to offer no ${ }^{1}$ The MENA countries are brought in here for comparison purposes given that some of the members are African countries. Moreover it is likewise a developing region that could be comparable to another developing region to benchmark the observed trend in our region of focus. 
Table 1. Trends in economic growth and school enrollment in SSA and MENA.

\begin{tabular}{|c|c|c|c|c|c|c|c|c|}
\hline \multirow[t]{2}{*}{ Year } & \multicolumn{2}{|c|}{$\begin{array}{l}\text { GDP per capita growth } \\
\text { (annual \%) }\end{array}$} & \multicolumn{2}{|c|}{$\begin{array}{c}\text { Gross enrolment ratio, } \\
\text { primary }(\%)\end{array}$} & \multicolumn{2}{|c|}{$\begin{array}{c}\text { Gross enrolment ratio, } \\
\text { secondary }(\%)\end{array}$} & \multicolumn{2}{|c|}{$\begin{array}{c}\text { Gross enrolment ratio, } \\
\text { tertiary (\%) }\end{array}$} \\
\hline & SSA & MENA & SSA & MENA & SSA & MENA & SSA & MENA \\
\hline 1996 & 2.15 & 2.99 & 73.93 & 95.24 & 24.67 & 62.60 & 3.89 & 17.44 \\
\hline 1997 & 0.54 & 1.59 & 77.53 & 95.46 & 25.01 & 64.32 & 3.99 & 18.3049 \\
\hline 1999 & -0.43 & 0.32 & 79.89 & 97.12 & 25.88 & 67.90 & 4.13 & 20.30 \\
\hline 2000 & 0.69 & 3.46 & 82.50 & 97.86 & 26.46 & 69.27 & 4.50 & 20.45 \\
\hline 2001 & 0.77 & 0.12 & 84.68 & 99.00 & 27.77 & 70.43 & 4.88 & 21.12 \\
\hline 2002 & 0.68 & 0.49 & 87.00 & 100.34 & 28.92 & 71.45 & 5.24 & 21.44 \\
\hline 2003 & 1.54 & 3.28 & 89.72 & 101.50 & 30.08 & 72.62 & 5.62 & 21.54 \\
\hline 2004 & 6.30 & 6.02 & 91.93 & 102.05 & 31.65 & 73.93 & 5.86 & 22.76 \\
\hline 2005 & 2.26 & 3.65 & 94.28 & 102.49 & 32.64 & 73.93 & 6.18 & 23.83 \\
\hline 2006 & 3.23 & 4.62 & 96.08 & 103.43 & 33.72 & 74.29 & 6.45 & 24.73 \\
\hline 2007 & 3.16 & 3.95 & 96.96 & 104.2 & 34.74 & 73.07 & 6.72 & 26.48 \\
\hline 2008 & 1.64 & 2.97 & 98.17 & 104.96 & 36.81 & 74.50 & 7.16 & 28.46 \\
\hline 2009 & -0.66 & -0.59 & 98.48 & 106.12 & 38.68 & 75.81 & 7.49 & 29.10 \\
\hline 2010 & 2.52 & 2.94 & 98.37 & 107.24 & 40.64 & 76.63 & 7.96 & 31.09 \\
\hline 2011 & 1.43 & 1.63 & 98.96 & 107.39 & 41.54 & 79.92 & 8.21 & 32.00 \\
\hline 2012 & 1.14 & 2.34 & 99.67 & 109.05 & 42.33 & 80.93 & 8.34 & 34.44 \\
\hline 2013 & 1.63 & 0.19 & 99.59 & 109.87 & 42.83 & 79.42 & 8.56 & 35.98 \\
\hline
\end{tabular}

Source: World Bank, WDI, 2016.

consensus regarding this hypothesis. It is likely that the inconsistent results accruing from current empiricism could partly be due to the aggregation of education rather than an analysis that takes into consideration the individual types of education. Different samples and methodologies have yielded mixed results. We examine the issue with disaggregated data on educational expansion taking into consideration the issue of endogeneity that has received little concern in the existing literature. In addition the gender question is introduced in the analysis to further understand the extent to which male education differ from female education in influencing economic growth. As evident in Table 2, educational expansion has been biased towards males in relation to females. For example, while the gender gap narrowed for primary school enrolment, reducing from 13.2 in 1995 to 7.2 in 2014, the data shows an increasing gap from 5.2 and 1.8 in 1995 to 6.4 and 2.7 in 2014 for secondary and tertiary enrolment respectively. The contribution of women to the economic performance of economies can however not be overemphasized. We envisage that the corresponding impact on per capita GDP would likewise depend on gender enrolment levels.

The innovations in this paper include, the extension of the endogenous growth framework based on the augmented Solow model proposed by [9]. This is achieved by accommodating gender-specific enrolment to estimate the impact of male and female enrolment at primary, secondary and tertiary educational 
Table 2. Enrolment in SSA by Gender.

\begin{tabular}{|c|c|c|c|c|c|c|c|c|c|}
\hline & \multicolumn{3}{|c|}{ Primary school enrollment } & \multicolumn{3}{|c|}{ Secondary school enrollment } & \multicolumn{3}{|c|}{ Tertiary enrollment } \\
\hline & Male & Female & Gap & Male & Female & Gap & Male & Female & Gap \\
\hline 1995 & 81.8 & 68.6 & 13.2 & 26.9 & 21.7 & 5.2 & 4.7 & 2.9 & 1.8 \\
\hline 2000 & 87.9 & 75.2 & 12.7 & 29.2 & 23.4 & 5.8 & 5.2 & 3.6 & 1.6 \\
\hline 2005 & 98.4 & 87.5 & 10.9 & 36 & 28.6 & 7.4 & 7.2 & 4.9 & 2.3 \\
\hline 2010 & 99.9 & 93.2 & 6.7 & 43.9 & 36.4 & 7.5 & 9.2 & 6.5 & 2.7 \\
\hline 2014 & 102 & 94.8 & 7.2 & 45.9 & 39.5 & 6.4 & 9.9 & 7.2 & 2.7 \\
\hline
\end{tabular}

Source: World Bank world development indicators.

levels on economic growth. Furthermore, we identify and estimate the gender-disaggregated growth effects of male and female enrolment at different levels of education. Above all, however, the health channel is hypothesized an important driver of the observed linkage between education and growth.

The empirical arena is characterized by scarcity of studies which examine the effects of education on growth at a gender disaggregated level. Exceptions include [33] [34] and [35]. Gender disaggregated analysis is important since evidence shows that educating girls just like boys increases a country's stock of human capital and growth [35]. Particularly in the African setting where most cultures try to lock the girl child outside school and only looks at her as potential house-wife or to put it bluntly "kitchen material", the progress made during the last decades in enrolling girls in schools needs attention. Certainly we agree with inter alia [36] and [37], that there is a further benefit in educating girls because of the positive influence of mothers on the education and health of their children. It needs to be pointed out that there is a relation of female education after ninth grade and slower population growth. This has implications for policy. We are not questioning the hypothesis prior mentioned and tested extensively in literature that education makes children healthier. The argument instead would like to stress that healthier children reduce infant mortality and thereby increase population growth, logically ceteris paribus lowering per capita growth rates. Against such a background, the focus of this paper on examining the gender-disaggregated effects of education on growth among other factors needs no further emphasis.

The current study is deemed justifiable given the incessant need to design evidence-based policies to promote the relevant type of education that would help steer economic growth since, as observed before, in general, education and economic performance are likely to be interlinked [38]. Given the limited resources in developing countries, disagreements exist as to whether investment should be prioritized on primary, secondary or tertiary education. We provide empirical evidence regarding the relationship between the latter three and economic performance for effective policy design. It should be remarked that the period under analysis (1995-2016) witnessed a number of reforms from both economic and educational perspectives principally for purposes of accelerating 
growth and human capital improvement among the populace. For example, a number of countries embraced universal education in different ways and in different amounts of investment. We are therefore motivated by the necessity to identify the potential effect of the different levels of school enrolment on per capita GDP growth during a period that witnessed educational expansion in primary, secondary and tertiary education in varying degrees.

The main contribution of this paper is to offer insights on how gender disaggregated human capital would affect economic growth but more importantly to analyse the role of health in this relationship. We therefore attempt to incorporate the effects of the different levels of education to investigate the level and growth effect of gender disaggregated human capital on economic growth. Furthermore, our choice of a set of Sub-Saharan African countries for study is informed by the need to provide richer evidence on a set of economies from the same region that share a variety of characteristics with regard to socio-economic development. We focus on whether school enrolment rates are associated with growth given the theoretical underpinning that school enrolments would generally generate rapid growth in human capital or productivity. The results from our application of an extended [9] model indicate that education affects economic growth in a positive and more significant way than the other two enrolment rate levels. If we change tertiary enrolment by one percent, we would expect GDP per capita to change by 0.14 percent. A similar change in secondary enrolment rate however produces a 0.42 percent change in growth whereas primary enrolment rate relatedly registers a lower impact of 0.29 percent. These findings are in line with what is documented in inter alia [39] [40] [41] [42] and [43]. Similarly, the facilitative role of health in the observed association between educational expansion and per capita GDP is likewise confirmed in the data. The results are robust to the use of alternative samples and specifications, alternative measures of education, and the removal of outliers in the data. A robustness exercise carried out to determine the effect of education on education based on each of these sensitivity analyses yields no substantial differences in terms of results in relation to the baseline output.

The rest of the paper is organized as follows. Section 2 details related literature and in Section 3 is discussed the methodology and data. Section 4 presents and discusses the results, while the robustness checks and concluding remarks respectively are contained in Sections 4 and 5 .

\section{Related Literature}

Existing literature is not devoid of studies that have ventured into examining the nexus between education and economic growth. Interestingly, we find mixed evidence characterized often by contradictory and inconclusive discussion on the relationship between the two. Therefore we categorize this literature under three perspectives.

In the first category, findings point to the positive impact of education on economic growth e.g. [40] [44]-[50] and [11]. [50] in particular, examines the 
determinants of economic growth in Guatemala during the period 1951-2002, with a particular focus on schooling. Using the error-correction model, the authors find that a better educated labour force has a positive and significant impact on economic growth during. Primary education documented more important than secondary and tertiary education. Similar conclusions are drawn in a study by [51] who examine the impact of increased school enrollment with regard to economic growth and income inequality in Tanzania using a dynamic computable general equilibrium (DCGE) model. Findings there from point to an increase in human capital formation in the long run leading to higher economic growth rates and increases household incomes in a Pareto sense. In terms of the distribution of the gains from economic growth, however, the results show that the positive effects of enhanced human capital formation are rather moderate and hence income inequality does not change substantially. Note that the simulation carried out focuses on a government program that aims at increasing primary school enrollment, leaving out the other types of enrollment-secondary and tertiary enrollment.

A previous study by [52], using the mean years of schooling for employed workers in his estimation to proxy education based on the growth accounting framework, documents a strong influence of education on economic growth in Australia between 1960 and 2000. This positive association is confirmed in a study by [45] on Pakistani and Sri Lanka, when the human capital is proxied by secondary school enrollment. Later on [53], in their study on New Zealand, concur with the positivity argument when they specifically show that increases in the proportion of employees with bachelor's degrees and above are highly correlated to increases in the average gross domestic product per person.

Note that just like the aforementioned empirical works, many studies on the subject are country-based whose results may not apply to aggregated countries given the heterogeneity of characteristics. Exceptions include a very recent study by [54] who analyse the relationship between School Education and Economic Growth in the SAARC Countries. The results for dynamic panel data models reveal that tertiary education enrollment has highest positive impact on growth in comparison to primary and secondary education enrollment. Support for this finding can also be found in [55] who examines the impact of education on growth in LDCs and advanced countries in the panel of 20 economies with focus on public expenditure on education, used as a proxy for investment in human capital. However, the results from his estimation of an empirical model based on the extended Cobb-Douglas production function with three inputs of labour, physical capital and human capital show that education indicator is both significant and robust to structural breaks in data or extreme observations only in the case of the advanced member states. A year after, a study by [32] on SSA using cross-section panel data regression, finds positive correlations between growth and various definitions of human capital, viz., literacy rate, average years of schooling, primary and secondary school enrolment as proxies for education. The third form of educational expansion, Tertiary enrolment, is left out of the 
despite its increasing role in shaping the knowledge base crucially needed for research and development, skills acquisition and labour productivity all of which can spill-over into economic growth [56].

The second category of studies considers the deleterious role of education on economic growth (e.g. [40] [45] [46], and [11]). [45] for example, finds a negative impact of primary school enrollment on economic growth in Pakistan and Sri Lanka. Similarly, in their attempt to investigate the effect of male and female higher education on economic growth in Greece over the period 1975-2012, [56], using enrolment rates by gender, as a proxy of quantity of human capital, find no long-run co-integrating relationship between males and females with higher education, physical capital investments and economic growth. Likewise, the shortrun results are found to be statistically insignificant for males and females with higher education. The authors also record evidence of unidirectional short-run Granger causality running from males and females with higher education to economic growth. We argue that basing on a country analysis may not afford a generalization of the results to an aggregation of countries. Moreover their analysis is based on a developed nation with different characteristics from developing nations.

In the aforementioned study by [55] on the impact of education on growth in LDCs, the author fails to find satisfactory evidence of the role of education in economic growth for the post-communist countries. On the other hand, in his survey of the recent literature that analyse the link between education and growth, [4] contrasts the Lucas approach, in which growth is affected by the accumulation of human capital, with the Nelson-Phelps approach, where growth is affected by the stock of human capital and by its interaction with the underlying process of technological innovation. The author then argues that growth in countries that are close to the world technological frontier benefit more from tertiary education, whereas countries that lie below the frontier benefit more from primary and secondary education.

The final category of findings points to weak or lack of evidence in data that human capital affects economic growth. For example, [57], using evidence from the labour literature labour literature on Mincerian returns to education and historical attainment data from UNESCO, and calibrating a model to determine how much of this relationship reflects causality running from schooling to growth, find that the channel from schooling to growth is too weak to plausibly explain more than one third of the observed relation between schooling and growth. The authors however note that the relation between schooling and growth observed in the data could be a reflection of omitted factors that are related to both schooling and growth rates in the study period 1960-1990, the identification of which is left for further studies.

On their part, [58] uses a nonparametric local-linear regression estimator and a nonparametric variable relevance test to conduct a rigorous and systematic search for significance of mean years of schooling by examining five of the most 
comprehensive schooling databases. The results suggest that mean years of schooling is not a statistically relevant variable in growth. However, the authors find evidence within a cross-sectional framework that educational achievement, measured by mean test scores, may provide a more reliable measure of human capital than mean years of schooling.

To date, the indirect effect of education via health on economic growth has been little explored in the empirical literature. It is also evident that while most of the studies have concentrated on developed countries, empirical evidence regarding the effect of education on economic growth in developing countries, SSA inclusive is still scarce. Moreover the results appear to be driven by sample choice, econometric techniques, and period specifications, observed and unobserved country-specific effects.

\section{Methodology and Data}

\subsection{The Model}

The model adopted in the current study is a variant of the augmented Solow model proposed by [9] in which human capital is one of the potential determinants of economic growth ${ }^{2}$. Specifically, our model follows [59] and [60], taking the form:

$$
P C_{i t}=F\left[H_{i t}, X_{i t}\right]
$$

where, $P C_{i t}$ is per capita GDP for each country $i$ at time $t, H_{i t}$ represents a set of human capital variables for country $i$ at time $t$, and the vector $X_{i t}$ represents a set of other variables for each country $i$ at time $t$. We can econometrically express Equation (1) as:

$$
P C_{i t}=\beta_{0}+\sum_{n=1}^{N} \beta_{i} H_{i t}+\sum_{n=1}^{N} \delta_{i} X_{i t}+\varepsilon_{i t}
$$

Given the potential of lagged income to affect current income, we introduce a lagged income variable in Equation (2) and re-write equation it in logarithm form as:

$$
\log P C_{i t}=\beta_{0}+\beta_{1} \log P C_{i t-1}+\beta_{i} \sum_{n=1}^{m} \log H_{i t}+\delta_{i} \sum_{j=1}^{k} X_{i t}+\varepsilon_{i t}
$$

where $X_{i t}$ includes variables like capital stock, inflation (controlling for macroeconomic stability), foreign direct investment inflows, private domestic investment, population growth and trade openness, and $\varepsilon_{i t}$ is the error term. $\log P C_{i t}$ is the logarithmic value of per capita GDP growth rate in country $i$ at period $t, \log P C_{i t-1}$ also referred to as the initial level of income in our study, is included to capture the lagged effect of GDP percapita; $\log H_{i t}$ is the $\log$ of human capital in country $i$ at period $t$. With regard to the latter, there are various indicators or measures of educational investment that are identified in the literature that include: Enrolment, Participation (or daily attendance rates), and ${ }^{2}[9]$ shows that a simple neoclassical model can explain up to $80 \%$ of the cross-country variation in the log of per capita GDP, especially if it incorporates differences in human capital investment across countries. 
Completion (years of school completed). Following [7] and [61], and based on data availability, we focus on enrolment proxied by school enrolment at the primary, secondary and tertiary levels, all in gross percentage terms. Each one of these indicators is considered independently and later in consideration with gender. However, as a robustness exercise we also consider mean years of schooling ${ }^{3}$.

Equation (3) is a dynamic specification of the model. However, it is critical to note that the inclusion of lagged percapita income variable could present severe endogeneity issues. As such, the use of static estimation methods such as the ordinary least squares (OLS), and fixed and random effects are likely to produce unreliable and misleading results. In this regard, the Generalized Method of Moments (GMM), first suggested by [62] and later developed further by [63]. Procedurally, the dynamic GMM first eliminates the individual effect from dynamic growth model by taking differences, instruments the right-hand side variables by using their lagged values and finally eliminates the inconsistency arising from the endogeneity of the explanatory variables. The consistency of the GMM estimator depends first on a Sargan test of over-identifying restrictions which tests the overall validity of the instruments, such that the rejection of the null hypothesis implies that the model is fit. However, the Sargan test may not be necessary when robust standard errors are instead used in the estimation.

The use of the GMM method includes employing an "Arellano-Bond" test to examine the null hypothesis that the error term is not serially correlated. This paper follows this procedure and applies one-step estimators which use weighting matrices that are independent of estimated parameters, instead of the two-step estimators that apply optimal weighting matrices in which the moment conditions are weighted by a consistent estimate of their covariance matrix. The basis of our choice is the small sample size that is commonly problematic for the two-step GMM estimator from the perspective of instrument proliferation. The one-step GMM, in addition to taking care of this anomaly, overcomes the usual tendency for the estimated standard errors under the two-step GMM to be small [64].

In addition, based on our earlier complementarity argument, we examine whether the educational role in the GDP per capita could be dependent on health expenditure. To test this hypothesis, we include interactions of education for each of the educational expansion indicator (primary, secondary and tertiary) and for enrolment type disaggregated by gender, with health expenditure.

\subsection{Data}

We have already acknowledged that literature unanimously supports the inclu-

\footnotetext{
${ }^{3}$ Annual data on participation, completion rates and literacy rates is insufficient for many countries in our sample. Therefore, we leave them out in our analysis. Since literature asserts that these are much correlated with schooling and enrolment, we hope our choice of the latter suffices as proxy for education. Moreover, we are focusing on educational expansion, which is directly linked to school enrolment [7].
} 
sion of human capital in models of economic growth. However, we find less clarity regarding the best measure of education to proxy human capital on its impact on economic growth. Different proxies of education such as literacy rates (e.g. [32]), average levels of educational Attainment (e.g. [65] [66]), mean years of schooling (e.g. [52]) and school enrolments (e.g. [7] and [67]) can be traced in literature. As on earlier suggested, we use the latter measure for the reasons already advanced but it is also in line with inter alia [68] [69] and [70]. Note that enrolment rates capture gross new investment in human capital per year. Replacement investment per year (for those who retire or die) is very large, especially in Africa where mortality rates are higher. Replacement investment flows embody the newer knowledge and technologies which presumably are productive, something enrolment levels miss. Rates of investment rather than percentages of the population attaining various education levels would also be more consistent with our FDI and Private domestic investment measures, giving a fairer comparison to investment flows (not stocks or levels) in physical capital. Certainly our adoption of the measure may not be a fatal flaw but would only mean that our estimates may be conservative because they do not include the effects from the embodiment of new technologies in replacement investment in human capital. Moreover, this new technology effect may be less important in Africa where the focus needs to be on the lower levels of education where most of the action from Education for All has been.

On the quality side, which is a big issue in Africa, Enrolment rates and levels both reflect quality somewhat because dropouts fall and parents and children respect the schools more as quality improves. Additionally, [8] consider differences in the impact of education on growth based on gender, in part because of different degrees of gender discrimination embedded in different countries. The latter issue is not uncommon in developing countries. The study covers 36 SSA countries with complete data over the period 1995-2016 covering 22 years. The model variables and data source are presented in Table 3 while Table 4 presents the descriptive statistics of the selected variables and the pairwise correlation matrix is given in Table 5 .

The high correlation between tertiary and secondary enrolment on the one hand and primary and secondary on the other in Table 5 suggests that we use separate specifications for each type of education expansion to guard against multicollinearity ${ }^{4}$. Otherwise the rest of the variables exhibit no multicollinearity issues. Note that multicollinearity is a type of disturbance in the data where if present, the statistical inferences made about the data may not be reliable.

\section{Results and Discussion}

\subsection{Stationarity or Unit Root Test}

As a pre-estimation sensitivity analysis, we carried out a Stationarity or unit root test of the variables employed in the current study. The results from Fisher unit root test are presented in Table 6. As a measure of robustness, the test computes

${ }^{4}$ Multicollinearity occurs when independent variables in a regression model are correlated. 
Table 3. Data sources and measurement.

\begin{tabular}{ccc}
\hline Variable & Measurement and Expected sign & Source \\
\hline Lagged GDP per capita & + & World Bank WDI \\
Inflation & +- & World Bank WDI \\
Infrastructure & + & World Bank WDI \\
FDI inflows & + & World Bank WDI \\
Private Domestic investment & + & World Bank WDI \\
Openness & + & World Bank WDI \\
Health & + & World Bank WDI \\
Tertiary Enrolment rate & + & World Bank WDI \\
Secondary Enrolment rate & + & World Bank WDI \\
Primary Enrolment rate & + & World Bank WDI \\
Mean years of schooling & + & HDI index \\
\hline
\end{tabular}

Source: Authors' calculations.

Table 4. Descriptive statistics.

\begin{tabular}{cccccc}
\hline Variables & Mean & Std. Dev. & Min & Max & Observations \\
\hline GDP per capita & 6.644 & 1.155 & 4.175 & 10.032 & 917 \\
Inflation & 52.209 & 859.793 & -35.837 & 24411 & 841 \\
FDI inflows & 0.803 & 1.587 & -11.513 & 5.087 & 868 \\
Private Domestic Investment & 2.454 & 0.693 & -1.742 & 4.830 & 685 \\
Population growth & 2.549 & 0.949 & -2.629 & 7.918 & 919 \\
Openness & 4.249 & 0.478 & 3.043 & 6.276 & 863 \\
Primary enrolment rate & 4.491 & 0.322 & 3.367 & 5.026 & 735 \\
Secondary enrolment rate & 3.455 & 0.637 & 1.636 & 4.739 & 517 \\
Tertiary enrolment rate & 1.309 & 0.978 & -1.562 & 3.682 & 466 \\
Health expenditure & 1.629 & 0.371 & 0.369 & 2.667 & 832 \\
Years of schooling & 1.373 & 0.525 & -0.105 & 2.332 & 901
\end{tabular}

Source: Authors' calculations.

four different unit root test statistics. It is evident from the results that all the four tests strongly reject the null hypothesis that all the panels contain unit roots. It is argued that when the number of panels is finite, the inverse $\chi^{2}$ test is powerful and applicable [71]. The current study comprises of a finite number of panels. Therefore, on the basis of the inverse $\chi^{2}$ test, the null hypothesis of unit root is strongly rejected, leading us to conclude that at least one of the panels has no unit root and this removes the tendency of possible spurious regressions or unrelated regressions [72]. 
Table 5. Pairwise correlation matrix.

\begin{tabular}{cccccccccc}
\hline & INFL & FDI & PDI & POPN & OPEN & PR_EN & SE_EN & TE_EN HEA \\
\hline INFL & 1 & & & & & & & \\
FDI & -0.0124 & 1 & & & & & & \\
PDI & -0.0635 & $0.3861^{*}$ & 1 & & & & & \\
POPN & -0.0363 & 0.1088 & -0.0211 & 1 & & & & \\
OPEN & 0.0215 & $0.5038^{*}$ & $0.3588^{*}$ & $-0.1333^{*}$ & 1 & & & \\
PR_EN & -0.0142 & $0.2539^{*}$ & $0.2572^{*}$ & -0.0721 & $0.2640^{*}$ & 1 & & \\
SE_EN & -0.0553 & $0.2055^{*}$ & $0.2624^{*}$ & $-0.5203^{*}$ & $0.4493^{*}$ & $0.5814^{*}$ & 1 & & \\
TE_EN & -0.1539 & 0.1626 & $0.3419^{*}$ & $-0.2944^{*}$ & $0.3806^{*}$ & $0.4732^{*}$ & $0.7489^{*}$ & 1 & \\
HEA & -0.0275 & -0.0347 & -0.1212 & -0.0977 & $-0.1706^{*}$ & 0.1243 & 0.0591 & 0.0431 & 1 \\
\hline
\end{tabular}

Notes: * Means $1 \%$ level of significance; INFL, FDI, PDI, POPN, OPEN, PR_EN, SE_EN, TE_EN, and HEA, respectively stand for inflation, FDI inflows, Private domestic investment, openness, primary enrolment, secondary enrolment, tertiary enrolment and health expenditure. All variables are in log. Source: Authors' computations from the data in World Development Indicators.

Table 6. Fisher Unit root test of Variables based on ADF.

\begin{tabular}{|c|c|c|c|c|c|c|c|c|}
\hline \multirow{2}{*}{ Variables } & \multirow{2}{*}{$\begin{array}{c}\text { Inverse } \\
\text { Statistic }\end{array}$} & \multirow{2}{*}{$\begin{array}{l}\chi^{2} \\
\text { Prob. }\end{array}$} & \multicolumn{2}{|c|}{$\begin{array}{l}\text { Inverse } \\
\text { Normal }\end{array}$} & \multicolumn{2}{|c|}{ Inverse Logit $t$} & \multicolumn{2}{|c|}{ Modified inv. $\chi^{2}$} \\
\hline & & & Statistic & Prob. & Statistic & Prob. & Statistic & Prob. \\
\hline Lagged GDP & 195.1923 & 0.000 & -6.101 & 0.000 & -5.716 & 0.000 & 5.377 & 0.000 \\
\hline Inflation & 758.787 & 0.000 & -20.861 & 0.000 & -27.933 & 0.000 & 43.741 & 0.000 \\
\hline FDI Inflows & 460.694 & 0.000 & -14.574 & 0.000 & -16.526 & 0.000 & 22.960 & 0.000 \\
\hline $\begin{array}{c}\text { Private Domestic } \\
\text { Investment }\end{array}$ & 304.221 & 0.000 & -10.479 & 0.000 & -11.437 & 0.000 & 15.332 & 0.000 \\
\hline Population Growth & 1090.973 & 0.000 & -26.667 & 0.000 & -39.474 & 0.000 & 64.702 & 0.000 \\
\hline Openness & 297.808 & 0.000 & -9.499 & 0.000 & -9.669 & 0.000 & 12.173 & 0.000 \\
\hline Primary Enrolment & 330.581 & 0.000 & -11.311 & 0.000 & -12.041 & 0.000 & 15.711 & 0.000 \\
\hline Secondary Enrolment & 164.785 & 0.000 & -5.177 & 0.000 & -5.426 & 0.000 & 6.703 & 0.000 \\
\hline Tertiary Enrolment & 160.743 & 0.000 & -5.424 & 0.000 & -5.799 & 0.000 & 7.951 & 0.000 \\
\hline Health Expenditure & 356.968 & 0.000 & -12.323 & 0.000 & -12.664 & 0.000 & 16.091 & 0.000 \\
\hline Mean Years of Schooling & 383.582 & 0.000 & -11.441 & 0.000 & -13.034 & 0.000 & 17.854 & 0.000 \\
\hline
\end{tabular}

Source: Authors' calculations.

\subsection{Empirical Results}

The main focus of the current study was to examine the impact of educational expansion on economic growth either directly or indirectly via an improvement in health. The results are presented in Table 7 and Table 8 with robust standard errors from the GMM estimation. We present and discuss first, the findings in line with the main objective and then comment on any additional observations from the data. 
Table 7. Results for the impact of education on real GDP per capita (in logarithm) in SSA.

\begin{tabular}{|c|c|c|c|c|c|c|}
\hline Model & Tertiary & Secondary & Primary & TER_HEA & SEC_HEA & PRI_HEA \\
\hline & (1) & (2) & (3) & (4) & (5) & (6) \\
\hline \multirow[t]{2}{*}{ Lagged GDP per capita } & $0.6369^{\star * *}$ & $0.6624^{\star \star \star}$ & $0.7831^{* * *}$ & $0.6369^{\star * \star}$ & $0.6566^{\star \star \star}$ & $0.7842^{* * *}$ \\
\hline & $(0.0571)$ & $(0.0674)$ & $(0.0360)$ & $(0.0540)$ & $(0.0683)$ & $(0.0363)$ \\
\hline \multirow[t]{2}{*}{ Inflation } & 0.0006 & 0.0006 & -0.0002 & 0.0005 & 0.0006 & -0.0002 \\
\hline & $(0.0004)$ & $(0.0007)$ & $(0.0004)$ & $(0.0004)$ & $(0.0007)$ & $(0.0004)$ \\
\hline \multirow[t]{2}{*}{ FDI Inflows } & 0.0023 & $-0.0275^{\star * *}$ & $-0.0117^{\star}$ & 0.0021 & $-0.0285^{\star * *}$ & $-0.0120^{*}$ \\
\hline & $(0.0076)$ & $(0.0079)$ & $(0.0064)$ & $(0.0079)$ & $(0.0084)$ & $(0.0066)$ \\
\hline \multirow[t]{2}{*}{ Private Domestic Investment } & $0.1240^{* * *}$ & $0.0988^{\star * *}$ & $0.1063^{\star * *}$ & $0.1236^{* * *}$ & $0.0983^{\star *}$ & $0.1060^{* * *}$ \\
\hline & $(0.0415)$ & $(0.0383)$ & $(0.0323)$ & $(0.0417)$ & $(0.0385)$ & $(0.0322)$ \\
\hline \multirow[t]{2}{*}{ Population Growth } & -0.0052 & $-0.0298^{\star}$ & $-0.0276^{\star}$ & -0.0040 & $-0.0305^{\star}$ & $-0.0279^{\star}$ \\
\hline & $(0.0096)$ & $(0.0161)$ & $(0.0150)$ & $(0.0094)$ & $(0.0163)$ & $(0.0152)$ \\
\hline \multirow[t]{2}{*}{ Openness } & -0.1273 & $-0.2478^{\star}$ & -0.1182 & -0.1273 & -0.2415 & -0.1187 \\
\hline & $(0.0946)$ & $(0.1458)$ & $(0.1020)$ & $(0.0928)$ & $(0.1474)$ & $(0.1024)$ \\
\hline \multirow[t]{2}{*}{ Health Expenditure } & -0.0584 & 0.0471 & -0.0015 & -0.0935 & -0.2173 & -0.3025 \\
\hline & $(0.0965)$ & $(0.1108)$ & $(0.0823)$ & $(0.0965)$ & $(0.4518)$ & $(0.9678)$ \\
\hline \multirow[t]{2}{*}{ Tertiary Enrolment } & $0.1434^{* * *}$ & & & 0.0839 & & \\
\hline & $(0.0486)$ & & & $(0.1308)$ & & \\
\hline \multirow[t]{2}{*}{ Secondary Enrolment } & & $0.4156^{* * *}$ & & & 0.2796 & \\
\hline & & $(0.1511)$ & & & $(0.2615)$ & \\
\hline \multirow[t]{2}{*}{ Primary Enrolment } & & & $0.2914^{* *}$ & & & 0.1901 \\
\hline & & & $(0.1382)$ & & & $(0.3849)$ \\
\hline \multirow[t]{2}{*}{ Tertiary $\times$ Health } & & & & 0.0378 & & \\
\hline & & & & $(0.0816)$ & & \\
\hline \multirow[t]{2}{*}{ Secondary $\times$ Health } & & & & & 0.0815 & \\
\hline & & & & & $(0.1383)$ & \\
\hline \multirow[t]{2}{*}{ Primary $\times$ Health } & & & & & & 0.0648 \\
\hline & & & & & & $(0.2120)$ \\
\hline Observations & 206 & 227 & 343 & 206 & 227 & 343 \\
\hline Countries & 32 & 31 & 35 & 32 & 31 & 35 \\
\hline $\begin{array}{l}\text { First order serial correlation } \\
\qquad(\mathrm{p} \text {-value })\end{array}$ & 0.0095 & 0.0169 & 0.0072 & 0.0095 & 0.0146 & 0.0075 \\
\hline $\begin{array}{l}\text { Second order serial correlation } \\
\qquad(\mathrm{p} \text {-value })\end{array}$ & 0.9108 & 0.3035 & 0.4997 & 0.8284 & 0.2158 & 0.5089 \\
\hline
\end{tabular}

Notes: TER_HEA, SEC_HEA and PRI_HEA respectively stand for interactions of tertiary, secondary and primary with health (i.e. Tertiary $\times$ Health, Secondary $\times$ Health, Primary $\times$ Health). Robust standard errors in parentheses; ${ }^{* *} \mathrm{p}<0.01,{ }^{* *} \mathrm{p}<0.05,{ }^{*} \mathrm{p}<0$. Source: Authors' calculations.

\subsubsection{Impact of School Enrolment on per Capita GDP}

From Columns (1) to (3) of Table 7, the impact of education in economic growth is undoubtedly positive and highly significant. Specifically, if we change tertiary enrolment by one percent, we would expect GDP per capita to change by 
Table 8. Gender disaggregated impact of education on real GDP per capita in logarithm.

\begin{tabular}{|c|c|c|c|c|c|c|c|c|c|c|c|c|}
\hline \multirow{2}{*}{ Model } & \multicolumn{2}{|c|}{ Tertiary } & \multicolumn{2}{|c|}{ Secondary } & \multicolumn{2}{|c|}{ Primary } & \multicolumn{2}{|c|}{ Tertiary $\times$ Health } & \multicolumn{2}{|c|}{ Secondary $\times$ Health } & \multicolumn{2}{|c|}{ Primary $\times$ Health } \\
\hline & Male & Female & Male & Female & Male & Female & Male & Female & Male & Female & Male & Female \\
\hline & (1) & (2) & (3) & (4) & (5) & (6) & (7) & (8) & (9) & (10) & (11) & (12) \\
\hline \multirow[t]{2}{*}{ Lagged GDP per capita } & $0.6612^{\star * *}$ & $0.6345^{* * *}$ & $0.7163^{* * *}$ & $0.6681^{\star * *}$ & $0.8066^{* * *}$ & $0.7856^{* * *}$ & $0.6751^{* * *}$ & $0.6476^{* * *}$ & $0.7095^{\star * *}$ & $0.6633^{* * *}$ & $0.8070^{* * *}$ & $0.7868^{* * *}$ \\
\hline & $(0.0559)$ & $(0.0411)$ & $(0.0629)$ & $(0.0672)$ & $(0.0280)$ & $(0.0350)$ & $(0.0567)$ & $(0.0465)$ & $(0.0652)$ & $(0.0682)$ & $(0.0286)$ & $(0.0359)$ \\
\hline Inflation & $(0.0004)$ & $(0.0004)$ & $(0.0007)$ & $(0.0007)$ & $(0.0004)$ & $(0.0004)$ & $(0.0004)$ & $(0.0004)$ & $(0.0007)$ & $(0.0007)$ & $(0.0004)$ & $(0.0004)$ \\
\hline \multirow[t]{2}{*}{ Population growth } & -0.0161 & -0.0128 & $-0.0277^{\star}$ & $-0.0278^{*}$ & $-0.0269^{*}$ & $-0.0247^{\star}$ & -0.0184 & -0.0121 & $-0.0287^{*}$ & $-0.0284^{*}$ & $-0.0269^{*}$ & $-0.0241^{\star}$ \\
\hline & $(0.0144)$ & $(0.0149)$ & $(0.0148)$ & $(0.0151)$ & $(0.0148)$ & $(0.0137)$ & $(0.0161)$ & $(0.0140)$ & $(0.0151)$ & $(0.0153)$ & $(0.0147)$ & $(0.0134)$ \\
\hline FDI inflows & 0.0021 & 0.0007 & $-0.0262^{* * *}$ & $-0.0289^{* * *}$ & $-0.0125^{*}$ & $-0.0140^{* *}$ & 0.0031 & 0.0039 & $-0.0274^{\star * *}$ & $-0.0300^{* * *}$ & $-0.0127^{\star}$ & $-0.0149^{* *}$ \\
\hline \multirow[t]{2}{*}{$\begin{array}{l}\text { Private domestic } \\
\text { investment }\end{array}$} & $0.1163^{\star \star \star}$ & $0.1208^{\star * *}$ & $0.1059^{* * *}$ & $0.0991^{\star * *}$ & $0.1045^{\star * *}$ & $0.0986^{* * *}$ & $0.1174^{* * *}$ & $0.1137^{\star * *}$ & $0.1058^{\star * *}$ & $0.0996^{\star * *}$ & $0.1040^{* * *}$ & $0.0975^{\star * *}$ \\
\hline & $(0.0299)$ & $(0.0309)$ & $(0.0403)$ & $(0.0383)$ & $(0.0308)$ & $(0.0293)$ & $(0.0294)$ & $(0.0297)$ & $(0.0404)$ & $(0.0385)$ & $(0.0306)$ & $(0.0292)$ \\
\hline \multirow[t]{2}{*}{ Openness } & -0.0877 & -0.0855 & -0.2235 & $-0.2456^{\star}$ & -0.0996 & -0.1143 & -0.0919 & $-0.1013^{*}$ & -0.2179 & $-0.2399^{*}$ & -0.0994 & -0.1137 \\
\hline & $(0.0595)$ & $(0.0698)$ & $(0.1374)$ & $(0.1370)$ & $(0.0938)$ & $(0.0976)$ & $(0.0579)$ & $(0.0584)$ & $(0.1391)$ & $(0.1386)$ & $(0.0939)$ & $(0.0981)$ \\
\hline \multirow{2}{*}{ Health expenditure } & -0.0459 & -0.0735 & 0.0352 & 0.0521 & -0.0213 & -0.0197 & -0.0128 & -0.0957 & -0.2873 & -0.1556 & -0.4044 & -0.7416 \\
\hline & $(0.0779)$ & $(0.0713)$ & $(0.1179)$ & $(0.1182)$ & $(0.0875)$ & $(0.0845)$ & $(0.1346)$ & $(0.0913)$ & $(0.5348)$ & $(0.3880)$ & (1.1093) & $(0.9357)$ \\
\hline \multirow[t]{2}{*}{$\begin{array}{l}\text { Tertiary enrolment, } \\
\text { male }\end{array}$} & $0.1076^{* *}$ & & & & & & 0.1384 & & & & & \\
\hline & $(0.0430)$ & & & & & & $(0.1306)$ & & & & & \\
\hline $\begin{array}{l}\text { Tertiary enrolment, } \\
\text { female }\end{array}$ & & $0.1201^{* * *}$ & & & & & & 0.0809 & & & & \\
\hline \multirow[t]{2}{*}{$\begin{array}{l}\text { Secondary enrolment, } \\
\text { male }\end{array}$} & & & $0.3545^{* *}$ & & & & & & 0.1944 & & & \\
\hline & & & $(0.1503)$ & & & & & & $(0.2704)$ & & & \\
\hline \multirow[t]{2}{*}{$\begin{array}{l}\text { Secondary enrolment, } \\
\text { female }\end{array}$} & & & & $0.3927^{* * *}$ & & & & & & 0.2816 & & \\
\hline & & & & $(0.1364)$ & & & & & & $(0.2220)$ & & \\
\hline \multirow{2}{*}{$\begin{array}{l}\text { Primary enrolment, } \\
\text { male }\end{array}$} & & & & & $0.2180^{*}$ & & & & & & 0.0897 & \\
\hline & & & & & $(0.1246)$ & & & & & & $(0.4274)$ & \\
\hline \multirow[t]{2}{*}{$\begin{array}{l}\text { Primary enrolment, } \\
\text { female }\end{array}$} & & & & & & $0.2646^{* *}$ & & & & & & 0.0095 \\
\hline & & & & & & $(0.1123)$ & & & & & & $(0.3788)$ \\
\hline \multirow[t]{2}{*}{$\begin{array}{c}\text { Tertiary } \times \text { Health, } \\
\text { male }\end{array}$} & & & & & & & -0.0261 & & & & & \\
\hline & & & & & & & $(0.0799)$ & & & & & \\
\hline \multirow[t]{2}{*}{$\begin{array}{c}\text { Tertiary } \times \text { Health, } \\
\text { Female }\end{array}$} & & & & & & & & -0.0058 & & & & \\
\hline & & & & & & & & $(0.0491)$ & & & & \\
\hline \multirow{2}{*}{$\begin{array}{l}\text { Secondary } \times \text { Health, } \\
\text { male }\end{array}$} & & & & & & & & & 0.0975 & & & \\
\hline & & & & & & & & & $(0.1585)$ & & & \\
\hline \multirow[t]{2}{*}{$\begin{array}{l}\text { Secondary } \times \text { Health, } \\
\text { female }\end{array}$} & & & & & & & & & & 0.0665 & & \\
\hline & & & & & & & & & & $(0.1212)$ & & \\
\hline Primary $\times$ Health, male & & & & & & & & & & & 0.0822 & \\
\hline
\end{tabular}




\section{Continued}

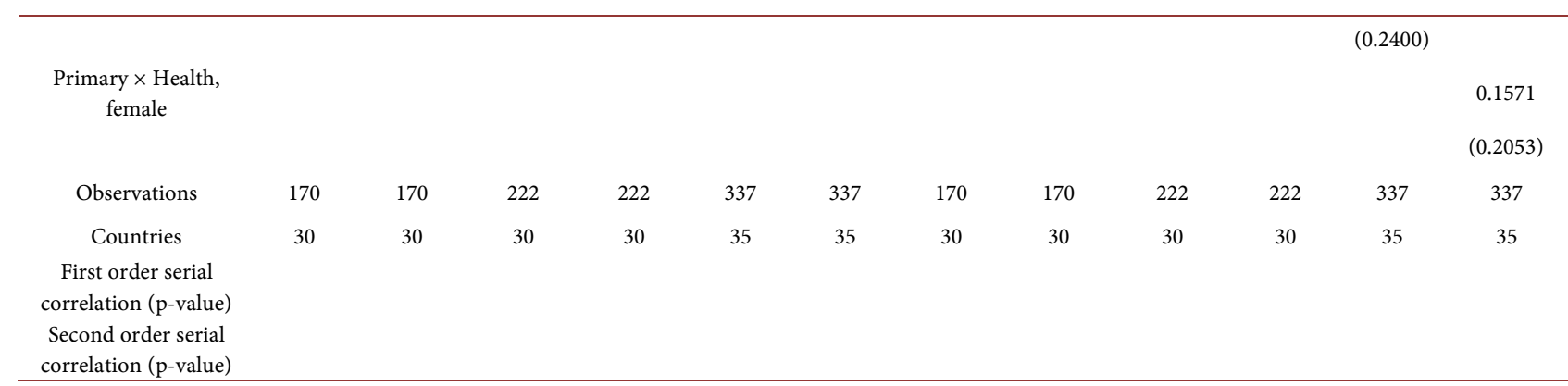

Note: "Tertiary $\times$ Health", "Secondary $\times$ Health", and, "Primary $\times$ Health" respectively stand for interactions of tertiary, secondary and primary education with health. Robust standard errors in parentheses: ${ }^{* *} \mathrm{p}<0.01,{ }^{* *} \mathrm{p}<0.05,{ }^{*} \mathrm{p}<0.1$. Source: Authors' calculations.

0.14 percent. A similar change in secondary enrolment however produces a 0.42 percent change in growth whereas primary enrolment relatedly registers a lower impact of 0.29 percent, where in the former case, the 0.42 percentage point increase in per capita growth due to secondary is without controls for the effects from primary and higher education enrolments. As found by [40] [41] [42] [43] [73], higher levels of education tends to generate higher growth rates more than the lower ones. In terms of magnitude, the greatest contribution to growth therefore is observed for secondary school investment followed by primary and tertiary educational expansion in order of importance. This result is particularly similar to that of [35] who found that the growth effect of education in Asia is still strongest at the secondary level. It is however interesting to note the size of the elasticity from their study was $0.24 \%$ compared to a whopping $0.42 \%$ for this study.

Overall the results are much more significant for females than for males. This is contrary to what [35] found for Asia where the converse was found to be the case. Furthermore, we find that secondary and tertiary enrolment is found most significant for either gender. Tertiary and secondary education output elasticity for females are larger and highly significant at $1 \%$ each, while primary education registers a $5 \%$ level of significance. On the male side, the corresponding levels of significance are $5 \%$ for either tertiary or secondary while primary education is significant at a $10 \%$ level. Specifically, we find that the growth effect of education in Sub Saharan Africa is still strongest at the secondary level. This can be seen both from the aggregated Table 7 (column 1, 2, 3) and the disaggregated Table 8 (columns 1-6) in line with the findings of [35].

Furthermore, contrary to what was found in Asia, female school enrolment effects outweigh those of the male. For instance, the average coefficients for female primary, secondary and tertiary respectively are $0.2646 \%, 0.3927 \%$, and $0.1201 \%$. The corresponding numbers for males are $0.2180 \%, 0.3545 \%$, and $0.1076 \%$. Because the regression is in log-log form, these coefficients represent elasticities. This result of a higher output elasticity of secondary enrolment for both gender than that of tertiary enrolment could be attributed to the fact that the social rate of return on investment in education at the tertiary level in Sub-Saharan Africa just as was found in Asia has been falling compared to that 
at the secondary level [35] [74]. However, it is important to note that the growth effects of tertiary education are nonetheless, positive and significant for both males and females and these effects are robust. Our finding is in contrast to previous research findings where no significant relationship was found between higher education and economic growth (see [75] [76] [77]). This could be attributed to the fact the high population growth in Sub-Saharan Africa where the youth population now constitute the largest proportion of the population coupled with the high cost, nature of skills acquired from tertiary education and the limited job opportunities have resulted in those with lower qualifications being easily absorbed by the labor market which through on-the-job training could maximize their earnings. This on the whole has resulted in a decline in the returns to tertiary education. Therefore, the opportunity cost of obtaining a higher education in terms of forgone income and by extension, skills acquisition is high.

What is even more interesting the revelation from this study of the progress made on the role of education in driving growth in Sub-Saharan Africa. Our results can also be compared to a previous panel study on Sub-Saharan Africa by [78] found that for the period 1960-2000, the contribution to economic growth from primary, secondary and higher education was $0.08 \%, 0.06 \%$ and $0.09 \%$, respectively compared the consistently larger contribution currently for all levels of education. These estimates are relatively low compared to the ones in the current study and a more recent study of [35] on Asia.

The second prominent feature of the results, based on the three enrolment measures in Table 6, is the discrepancy between the elasticity of output between female and male enrolments. At each level of enrolment, the growth effect of female education is higher than that of female education. This is an indication of the closing gender wage gap which can be attributed to the positive outcomes from the deliberate steps towards affirmative action that have taken root across the continent. This has for instance seen the emergence of female occupying positions of Head of State, Company Executives and Politicians among other spheres of socioeconomic importance. This has given impetus to the proactive involvement of the girl child in school activities. In fact, girl children routinely outperform boys in the examinations across the continent. Therefore, the elasticity of female and male education with respect to output per capita can be interpreted as their respective marginal productivities. As a result, the gap between the elasticity of output with respect to male and female enrolment per worker can be interpreted as a gender productivity differential [35]. Thus, the findings of a positive association between education and economic growth is in line with existing empirical evidence on the role of the human capital in growth which argues that a highly education-centred human capital accumulation effort positively impacts on economic growth by functioning as an input in the production process (see e.g., [5] [9] [79].

\subsubsection{Gender-Disaggregated School Enrolment, Health Expenditure and Economic Growth \\ While we fail to find significant evidence of the direct impact of health expendi-}


ture on economic growth in all specifications, the interaction of the same with educational expansion provides some important insights for policy. For example, in Columns (4) through (6) of Table 7, the health influence in the education-growth nexus is largest for secondary enrolment $(0.424 \%)$ followed by primary $(0.296 \%)$ and tertiary $(0.146 \%)$. As observed earlier, however, without health interaction in the relevant specification, the results almost remain stable, viz., $0.416 \%, 0.291 \%$ and $0.143 \%$ for the respective levels of education. By implication, increasing health expenditure does not substantially catalyse educational contribution to growth. We are reluctant to take this outcome at face value given the generally accepted view that health can enhance education. Perhaps disaggregating education enrolment by gender would offer better outcomes.

In columns (7) to (12) of Table 8, one striking observation is that economies are likely to gain from educational investment and female primary school enrolment in particular, if they also increase health expenditure. The quantitative extent of enhancement driven by increasing health expenditure is $0.32 \%$ for females in relation to $0.22 \%$ for their male counterparts. Specifically, without the interactive role of health, a $1 \%$ increase in female primary enrolment could lead to an increase in per capita GDP by about $0.26 \%$ (see Table 8 , column 6 ), whereas in the presence of improved health expenditure the total impact of primary school enrolment for females increases to about $0.35 \%{ }^{5}$. On the other hand, in the presence of increasing health expenditure the total impact of primary school enrolment for males on per capita GDP is $0.22 \%{ }^{6}$. Thus the indirect effect of education via health is substantially larger than the direct effects at least for primary school enrolment. Overall evidence suggests that exogenous improvements in health heighten the benefits of an increase in primary enrolment on economic growth. The observed effects would also imply that it is probable that primary and junior secondary education improve child health and mortality, but then after about 9 th grade for females the fertility effect of education in causing females to choose smaller family size (and use the technology) begins to dominate the better health effects, thereby slowing population growth. The slower population growth ceteris paribus with secondary education of girls both logically and in our regressions increases economic growth when the latter is measured on a per capita basis; hence, the negative coefficients for health expenditure as well as for population growth on per capita growth rates.

On the other hand, Table 8, Column (7) through (10) suggests that the indirect impact of secondary enrolment on growth via health is not substantially different from its direct effect explained earlier. Some slight improvement is however observed for tertiary education where in the presence of health expenditure, the total impact is calculated to be about $0.129 \%$ for females and $0.097 \%$ for males.

\subsubsection{Additional Findings}

Table 7 and Table 8 exhibit some interesting results about the control variables. ${ }^{5}$ The value $35 \%$ is derived as follows: $0.0095+0.1571(1.63)=0.3511$, where 1.63 is the sample mean value of health expenditure over the period of study.

${ }^{6}$ This outcome is similar to the effect of primary school enrolment for males on growth without interacting it with health (see Column 5). 
First, lagged GDP per capita is positively associated with current percapita income in all specifications pointing to divergence of per capita income across SSA. FDI inflows are found to influence negatively per capita growth when secondary and primary enrolments are included in the model but insignificant when tertiary education is controlled for. This finding is in line with previous studies such as [80] and is indicative of the profit repatriation and the "market-stealing effect" of FDI inflows to SSA. Intuitively, the result is suggestive of domestic firms being less productive and less competitive in relation to the foreign investors and deciding to leave the market, a scenario that would increase structural unemployment and therefore harm the economy. Similarly, the negative impact of FDI inflows exhibited in the data could be indicative of the economies' substantial dependence on foreign investors that are eventually allowed to repatriate profits, leaving a huge financial gap that domestic firms might not close in the short run.

On the other hand, private domestic investment is positive and statistically significant at 1 percent level (see columns (1) through (3) of Table 7) in line with [81] and [82]. Additionally, the finding of a positive relationship between percapita GDP and inflation recorded in Table 6, Columns 1, 2, 7 and 8, against our theoretical expectation. However, it is neither uncommon in literature nor meaningless. For example, [83] finds a structural break at $8 \%$ above which inflation becomes harmful to growth. A later study by [84] however indicates that the threshold inflation levels are $1 \%-3 \%$ and $11 \%-12 \%$ for the industrial and developing countries respectively. The result finds theoretical justification in the Tobin effect which suggests that inflation causes individuals to substitute money for interest earning assets, leading to greater capital intensity and a promotion of economic growth [85].

On the other hand, consistent with the type of dynamics in our model, the coefficient on the lagged per capita income has the expected sign. Specifically, the parameter corresponding to the variable throughout all the specifications in both Tables 8 and 9 is less than unity, positive and statistically significant. Similarly, as expected, and common in literature, there is a negative relationship between population growth and per capita GDP. For example, in Columns (2) through (6), Table 7, it is clear that for a one-unit increase in population growth, we expect to see about $3 \%$ of a decrease in the geometric mean of per capita GDP.

\section{Robustness Checks}

Besides the use of robust standard errors and the various model specifications, all of which clearly confirm the role of education on economic growth, we follow [58] and carried out several additional robustness checks, including testing for outlier sensitivity analysis, employing an alternative but commonly applied measure of education measurement, lagging the enrolment variables ${ }^{7}$, and subdividing the data into subsamples based on income levels as defined by the

${ }^{7}$ We also carried out other robustness checks such as employing alternative model specifications and estimation procedures but the baseline findings were not substantially altered. Therefore, we have not presented the results due to space but they are available on request. 


\section{World Bank.}

Available data shows that South Africa and Nigeria are not only the most populous but also contribute more than half of Africa's gross domestic product. In order to ensure that our results are not driven by such outliers, given GDP percapita as our dependent variable, the first robustness check we perform is to exclude the two countries and rerun the regressions to determine whether or not our primary results are robust to the removal of outliers. As emphasized by [86], if there are any outliers detected in the data, one needs to adopt econometric techniques that are robust to their presence for purposes of obtaining more precise and reliable outcomes. It is important to note however that the exclusion of the detected outliers in our data does not appear to substantially alter our original results in Table 7 . The results are presented in Table 9.

Table 9. Impact of interacted education with health on economic growth in SSA-subsample excluding Nigeria and South Africa.

\begin{tabular}{|c|c|c|c|c|c|c|}
\hline \multirow{2}{*}{ Model } & TER & SEC & PRI & TER_HEA & SEC_HEA & PRI_HEA \\
\hline & (1) & (2) & (3) & (4) & (5) & (6) \\
\hline \multirow[t]{2}{*}{ Lagged GDP per capita } & $0.6355^{* * *}$ & $0.6171^{* * *}$ & $0.7697^{* * *}$ & $0.6354^{* * *}$ & $0.6092^{* * *}$ & $0.7707^{\star * *}$ \\
\hline & $(0.0572)$ & $(0.0703)$ & $(0.0420)$ & $(0.0541)$ & $(0.0715)$ & $(0.0425)$ \\
\hline \multirow[t]{2}{*}{ Inflation } & 0.0006 & 0.0005 & -0.0002 & 0.0005 & 0.0005 & -0.0002 \\
\hline & $(0.0004)$ & $(0.0006)$ & $(0.0004)$ & $(0.0004)$ & $(0.0006)$ & $(0.0004)$ \\
\hline \multirow{2}{*}{ Population Growth } & -0.0050 & $-0.0231^{*}$ & $-0.0212^{\star}$ & -0.0038 & $-0.0236^{*}$ & $-0.0213^{*}$ \\
\hline & $(0.0096)$ & $(0.0127)$ & $(0.0110)$ & $(0.0094)$ & $(0.0127)$ & $(0.0109)$ \\
\hline \multirow[t]{2}{*}{ FDI Inflows } & 0.0025 & $-0.0254^{* * *}$ & -0.0102 & 0.0023 & $-0.0264^{* * *}$ & -0.0105 \\
\hline & $(0.0076)$ & $(0.0083)$ & $(0.0067)$ & $(0.0079)$ & $(0.0091)$ & $(0.0070)$ \\
\hline \multirow[t]{2}{*}{$\begin{array}{l}\text { Private Domestic } \\
\text { Investment }\end{array}$} & $0.1242^{* * *}$ & $0.0915^{\star *}$ & $0.1005^{\star * \star}$ & $0.1237^{\star * *}$ & $0.0904^{* *}$ & $0.1001^{\star \star \star}$ \\
\hline & $(0.0415)$ & $(0.0369)$ & $(0.0322)$ & $(0.0417)$ & $(0.0370)$ & $(0.0321)$ \\
\hline \multirow[t]{2}{*}{ Openness } & -0.1267 & $-0.2602^{*}$ & -0.1152 & -0.1268 & -0.2549 & -0.1158 \\
\hline & $(0.0947)$ & $(0.1554)$ & $(0.1080)$ & $(0.0929)$ & $(0.1564)$ & $(0.1087)$ \\
\hline \multirow[t]{2}{*}{ Health } & -0.0585 & 0.0376 & -0.0090 & -0.0936 & -0.2710 & -0.3294 \\
\hline & $(0.0965)$ & $(0.1112)$ & $(0.0818)$ & $(0.0964)$ & $(0.4698)$ & $(0.9749)$ \\
\hline \multirow[t]{2}{*}{ Tertiary Enrolment } & $0.1440^{* * *}$ & & & 0.0843 & & \\
\hline & $(0.0487)$ & & & $(0.1308)$ & & \\
\hline \multirow[t]{2}{*}{ Secondary Enrolment } & & $0.4561^{\star * *}$ & & & 0.2983 & \\
\hline & & $(0.1585)$ & & & $(0.2673)$ & \\
\hline \multirow[t]{2}{*}{ Primary Enrolment } & & & $0.3268^{* *}$ & & & 0.2184 \\
\hline & & & $(0.1553)$ & & & $(0.3988)$ \\
\hline \multirow[t]{2}{*}{ Tertiary $\times$ Health } & & & & 0.0379 & & \\
\hline & & & & $(0.0816)$ & & \\
\hline \multirow[t]{2}{*}{ Secondary $\times$ Health } & & & & & 0.0949 & \\
\hline & & & & & $(0.1459)$ & \\
\hline \multirow[t]{2}{*}{ Primary $\times$ Health } & & & & & & 0.0691 \\
\hline & & & & & & $(0.2136)$ \\
\hline Observations & 204 & 213 & 326 & 204 & 213 & 326 \\
\hline Countries & 31 & 30 & 34 & 31 & 30 & 34 \\
\hline
\end{tabular}

Notes: TER_HEA, SEC_HEA and PRI_HEA respectively stand for interactions of tertiary, secondary and primary with health (i.e. Tertiary $\times$ Health, Secondary $\times$ Health, Primary $\times$ Health). Robust standard errors in parentheses; ${ }^{* *} \mathrm{p}<0.01,{ }^{* *} \mathrm{p}<0.05,{ }^{*} \mathrm{p}<0.1$. Source: Authors' calculations. 
As a second robustness exercise, we employ an alternative measure typically included in empirical growth regressions as a proxy for human capital-the mean years of schooling. The results as presented in Table 10 emphasize the significant role of education in economic growth.

[7] notes that it would be better to use proxies for the initial stock of human capital per person rather than variables that relate to the flow of investment in human capital. In his argument, the stock of human capital derived from formal education depends on current and lagged values of school-enrolment rates. For this reason, we undertake more sensitivity analysis where enrolment is lagged by 5 years to reflect how well past levels of education expansion would translate into increased per capita GDP. This is based on the fact that average years of education change gradually over time, and that a change in the average level of school enrolment takes time to impact economic growth [58]. The results in Table 11 confirm the importance of educational expansion to growth as well as the facilitative role of health in that linkage. In other words, the potential long-run effect of education on economic growth is confirmed.

Table 10. Impact of schooling on economic growth.

\begin{tabular}{|c|c|c|}
\hline Model & Mean years of Schooling & Schooling $\times$ Health \\
\hline & (1) & (2) \\
\hline \multirow[t]{2}{*}{ Lagged GDP per capita } & $0.5663^{\star * *}$ & $0.5664^{* * *}$ \\
\hline & $(0.0974)$ & $(0.0990)$ \\
\hline \multirow[t]{2}{*}{ Inflation } & 0.0001 & 0.0001 \\
\hline & $(0.0001)$ & $(0.0001)$ \\
\hline \multirow[t]{2}{*}{ Infrastructure } & -0.0116 & -0.0112 \\
\hline & $(0.0289)$ & $(0.0313)$ \\
\hline \multirow[t]{2}{*}{ FDI Inflows } & $-0.0216^{* * *}$ & $-0.0217^{* * *}$ \\
\hline & $(0.0071)$ & $(0.0071)$ \\
\hline \multirow[t]{2}{*}{ Private Domestic Investment } & 0.0719 & 0.0715 \\
\hline & $(0.0529)$ & $(0.0508)$ \\
\hline \multirow[t]{2}{*}{ Openness } & $-0.2315^{\star *}$ & $-0.2297^{\star *}$ \\
\hline & $(0.0968)$ & $(0.0988)$ \\
\hline \multirow[t]{2}{*}{ Health Expenditure } & -0.2091 & -0.2422 \\
\hline & $(0.1358)$ & $(0.3434)$ \\
\hline \multirow[t]{2}{*}{ Mean years of schooling } & $1.3444^{\star * *}$ & $1.3010^{* * *}$ \\
\hline & $(0.2677)$ & $(0.3525)$ \\
\hline \multirow[t]{2}{*}{ Schooling $\times$ Health } & & 0.0240 \\
\hline & & $(0.1952)$ \\
\hline Observations & 435 & 435 \\
\hline Countries & 36 & 36 \\
\hline
\end{tabular}

Note: Robust standard errors in parentheses ${ }^{* * *} \mathrm{p}<0.01,{ }^{* *} \mathrm{p}<0.05,{ }^{*} \mathrm{p}<0.1$. Source: Authors' calculations. "Schooling $\times$ Health" stands for the interaction of schooling with health. 
Table 11. Lagged impact of education on per capita growth in SSA.

\begin{tabular}{|c|c|c|c|c|c|c|}
\hline Model & TER & SEC & PRI & TER_HEA & SEC_HEA & PRI_HEA \\
\hline & (1) & (2) & (3) & (4) & (5) & (6) \\
\hline \multirow[t]{2}{*}{ Lagged GDP per capita } & $0.6459^{* * *}$ & $0.7000^{* * *}$ & $0.7622^{* * *}$ & $0.6494^{* * *}$ & $0.7032^{* * *}$ & $0.7620^{* * *}$ \\
\hline & $(0.0774)$ & $(0.0390)$ & $(0.0363)$ & $(0.0771)$ & $(0.0397)$ & $(0.0405)$ \\
\hline \multirow[t]{2}{*}{ Inflation } & -0.0012 & $-0.0017^{\star *}$ & $-0.0003^{\star *}$ & -0.0012 & $-0.0025^{\star *}$ & -0.0015 \\
\hline & $(0.0028)$ & $(0.0008)$ & $(0.0001)$ & $(0.0028)$ & $(0.0011)$ & $(0.0014)$ \\
\hline \multirow[t]{2}{*}{ Population growth } & 0.0483 & 0.0121 & 0.0077 & 0.0468 & 0.0141 & 0.0093 \\
\hline & $(0.0466)$ & $(0.0171)$ & $(0.0111)$ & $(0.0471)$ & $(0.0180)$ & $(0.0115)$ \\
\hline \multirow[t]{2}{*}{ FDI Inflows } & 0.0117 & 0.0061 & -0.0028 & 0.0109 & 0.0062 & -0.0007 \\
\hline & $(0.0089)$ & $(0.0104)$ & $(0.0101)$ & $(0.0089)$ & $(0.0104)$ & $(0.0096)$ \\
\hline \multirow{2}{*}{$\begin{array}{c}\text { Private domestic } \\
\text { investment }\end{array}$} & $0.0730^{* * *}$ & $0.1023^{\star * *}$ & $0.0904^{\star *}$ & $0.0757^{\star * *}$ & $0.1006^{* * *}$ & $0.0880^{* *}$ \\
\hline & $(0.0249)$ & $(0.0378)$ & $(0.0368)$ & $(0.0235)$ & $(0.0348)$ & $(0.0356)$ \\
\hline \multirow[t]{2}{*}{ Openness } & -0.0179 & $-0.2322^{* *}$ & -0.0170 & -0.0210 & $-0.2159^{\star *}$ & -0.0050 \\
\hline & $(0.0584)$ & $(0.1085)$ & $(0.0887)$ & $(0.0564)$ & $(0.1035)$ & $(0.0898)$ \\
\hline \multirow[t]{2}{*}{ Health expenditure } & -0.0083 & 0.0013 & 0.1072 & -0.0101 & -0.0102 & 0.1038 \\
\hline & $(0.0982)$ & $(0.0763)$ & $(0.0909)$ & $(0.0957)$ & $(0.0792)$ & $(0.0887)$ \\
\hline \multirow[t]{2}{*}{$\begin{array}{l}\text { Tertiary Enrolment } \\
\text { (5 lags) }\end{array}$} & $0.1118^{\star *}$ & & & $0.1526^{*}$ & & \\
\hline & $(0.0477)$ & & & $(0.0842)$ & & \\
\hline \multirow[t]{2}{*}{$\begin{array}{l}\text { Secondary Enrolment } \\
\text { (5 lags })\end{array}$} & & $0.2403^{* * *}$ & & & $0.2039^{* *}$ & \\
\hline & & $(0.0653)$ & & & $(0.0817)$ & \\
\hline \multirow[t]{2}{*}{$\begin{array}{c}\text { Primary Enrolment } \\
\text { (5 lags) }\end{array}$} & & & 0.1315 & & & 0.1196 \\
\hline & & & $(0.1112)$ & & & $(0.1029)$ \\
\hline \multirow[t]{2}{*}{ Tertiary $\times$ Health $(5$ lags $)$} & & & & -0.0224 & & \\
\hline & & & & $(0.0370)$ & & \\
\hline \multirow[t]{2}{*}{$\begin{array}{c}\text { Secondary } \times \text { Health } \\
(5 \text { lags })\end{array}$} & & & & & 0.0060 & \\
\hline & & & & & $(0.0185)$ & \\
\hline \multirow[t]{2}{*}{ Primary $\times$ Health $(5$ lags $)$} & & & & & & 0.0033 \\
\hline & & & & & & $(0.0102)$ \\
\hline Observations & 149 & 184 & 280 & 149 & 182 & 277 \\
\hline Countries & 30 & 32 & 35 & 30 & 31 & 34 \\
\hline
\end{tabular}

Note: TER_HEA, SEC_HEA and PRI_HEA respectively stand for interactions of tertiary, secondary and primary with health (i.e. Tertiary $\times$ Health, Secondary $\times$ Health, Primary $\times$ Health). Robust standard errors in parentheses; ${ }^{* *} \mathrm{p}<0.01,{ }^{* *} \mathrm{p}<0.05,{ }^{*} \mathrm{p}<0.1$. Source: Authors' calculations.

A final robustness check is to establish the extent to which our results are driven by a given level of income. The alternative samples used are drawn from the main SSA sample using the World Bank categorization of income groups. In this regard, we intend to find out whether or not educational expansion has an impact that is contingent upon a nation's income level. The results are presented in Table 12. Tertiary education is found highly significant at a $10 \%$ level for low income countries only, just as primary education is for lower middle-income 
Table 12. Impact of education on growth by World Bank Income group categorisation.

\begin{tabular}{|c|c|c|c|c|c|c|c|c|c|c|c|c|}
\hline & $\begin{array}{l}\text { High } \\
\text { Income }\end{array}$ & $\begin{array}{l}\text { Lower } \\
\text { Middle } \\
\text { Income }\end{array}$ & $\begin{array}{l}\text { Upper } \\
\text { Middle } \\
\text { Income }\end{array}$ & $\begin{array}{c}\text { Low } \\
\text { Income }\end{array}$ & $\begin{array}{l}\text { High } \\
\text { Income }\end{array}$ & $\begin{array}{l}\text { Lower } \\
\text { Middle } \\
\text { Income }\end{array}$ & $\begin{array}{l}\text { Upper } \\
\text { Middle } \\
\text { Income }\end{array}$ & $\begin{array}{c}\text { Low } \\
\text { Income }\end{array}$ & $\begin{array}{l}\text { High } \\
\text { Income }\end{array}$ & $\begin{array}{l}\text { Lower } \\
\text { Middle } \\
\text { Income }\end{array}$ & $\begin{array}{l}\text { Upper } \\
\text { Middle } \\
\text { Income }\end{array}$ & $\begin{array}{l}\text { Low } \\
\text { Income }\end{array}$ \\
\hline & (1) & (2) & (3) & (4) & (5) & (6) & (7) & (8) & (9) & (10) & (11) & (12) \\
\hline \multirow[t]{2}{*}{ Lagged GDP per capita } & $0.317^{\star * *}$ & $0.779^{* * *}$ & $0.740^{* * *}$ & $0.556^{* * *}$ & $0.860^{\star * *}$ & $0.735^{* * *}$ & $0.970^{* * *}$ & $0.575^{\star * *}$ & $0.612^{* * *}$ & $0.760^{* * *}$ & $0.857^{\star * *}$ & $0.862^{* * *}$ \\
\hline & $(0.000)$ & $(0.036)$ & $(0.173)$ & $(0.094)$ & $(0.018)$ & $(0.142)$ & $(0.112)$ & (0.109) & $(0.114)$ & $(0.063)$ & $(0.031)$ & $(0.039)$ \\
\hline \multirow[t]{2}{*}{ Inflation } & $0.012^{* * *}$ & -0.010 & 0.000 & 0.002 & $-0.004^{* * *}$ & $-0.011^{* * *}$ & 0.001 & $-0.000^{* * *}$ & $-0.009^{* * *}$ & $-0.006^{* *}$ & -0.007 & -0.000 \\
\hline & $(0.000)$ & $(0.011)$ & $(0.001)$ & $(0.002)$ & $(0.000)$ & $(0.003)$ & $(0.001)$ & $(0.000)$ & $(0.002)$ & $(0.003)$ & $(0.009)$ & $(0.000)$ \\
\hline \multirow[t]{2}{*}{ FDI inflows } & $-0.027^{* * *}$ & -0.016 & $0.011^{* * *}$ & -0.002 & $-0.043^{* * *}$ & $-0.022^{*}$ & -0.015 & $-0.024^{\star *}$ & -0.026 & $-0.018^{\star}$ & -0.013 & -0.002 \\
\hline & $(0.000)$ & $(0.014)$ & $(0.004)$ & $(0.009)$ & $(0.005)$ & $(0.013)$ & $(0.029)$ & $(0.012)$ & $(0.017)$ & $(0.010)$ & $(0.016)$ & $(0.008)$ \\
\hline \multirow[t]{2}{*}{$\begin{array}{c}\text { Private domestic } \\
\text { investment }\end{array}$} & & $0.164^{\star *}$ & 0.130 & $0.111^{\star *}$ & $0.079^{* * *}$ & $0.262^{* * *}$ & -0.162 & $0.121^{* * *}$ & $0.024^{* * *}$ & 0.093 & $0.261^{*}$ & $0.118^{* *}$ \\
\hline & & $(0.081)$ & $(0.163)$ & $(0.049)$ & $(0.004)$ & $(0.079)$ & $(0.132)$ & $(0.039)$ & $(0.005)$ & $(0.072)$ & $(0.151)$ & $(0.058)$ \\
\hline \multirow[t]{2}{*}{ Population growth } & $-0.010^{* * *}$ & -0.134 & $-0.239^{* * *}$ & 0.025 & $-0.001^{\star * *}$ & $0.096^{*}$ & -0.182 & -0.008 & -0.007 & $0.091^{\star}$ & -0.124 & $-0.035^{\star *}$ \\
\hline & $(0.000)$ & $(0.109)$ & $(0.092)$ & $(0.021)$ & $(0.000)$ & $(0.053)$ & $(0.114)$ & $(0.020)$ & $(0.005)$ & $(0.052)$ & $(0.084)$ & $(0.017)$ \\
\hline \multirow[t]{2}{*}{ Openness } & $-1.249^{* * *}$ & -0.092 & 0.119 & $-0.188^{\star}$ & $0.162^{* * *}$ & -0.461 & -0.102 & -0.260 & 0.010 & -0.226 & -0.242 & -0.058 \\
\hline & $(0.000)$ & $(0.213)$ & $(0.165)$ & $(0.105)$ & $(0.001)$ & $(0.352)$ & $(0.105)$ & $(0.198)$ & $(0.017)$ & $(0.210)$ & $(0.285)$ & $(0.112)$ \\
\hline \multirow[t]{2}{*}{ Health expenditure } & & $-0.232^{\star}$ & $-0.397^{*}$ & -0.034 & $0.154^{* * *}$ & 0.046 & $-0.420^{* * *}$ & 0.105 & -0.455 & -0.106 & $-0.288^{\star * *}$ & 0.063 \\
\hline & & $(0.133)$ & $(0.234)$ & $(0.086)$ & $(0.043)$ & $(0.227)$ & $(0.113)$ & $(0.096)$ & $(0.297)$ & $(0.144)$ & $(0.077)$ & $(0.050)$ \\
\hline \multirow[t]{2}{*}{ Tertiary enrolment } & & -0.004 & 0.153 & $0.352^{\star * *}$ & & & & & & & & \\
\hline & & $(0.034)$ & $(0.161)$ & $(0.094)$ & & & & & & & & \\
\hline \multirow[t]{2}{*}{ Secondary enrolment } & & & & & $0.168^{\star * *}$ & 0.212 & $0.725^{\star *}$ & $0.450^{\star *}$ & & & & \\
\hline & & & & & $(0.002)$ & $(0.169)$ & $(0.350)$ & $(0.183)$ & & & & \\
\hline \multirow[t]{2}{*}{ Primary enrolment } & & & & & & & & & -1.340 & $1.042^{* * *}$ & -0.914 & 0.052 \\
\hline & & & & & & & & & $(0.946)$ & $(0.215)$ & $(0.569)$ & $(0.093)$ \\
\hline Observations & 5 & 56 & 34 & 113 & 15 & 67 & 47 & 98 & 21 & 103 & 55 & 164 \\
\hline Countries & 2 & 9 & 5 & 17 & 2 & 8 & 5 & 16 & 2 & 9 & 5 & 19 \\
\hline
\end{tabular}

Notes: Robust standard errors in parentheses; ${ }^{* *} \mathrm{p}<0.01,{ }^{* *} \mathrm{p}<0.05,{ }^{*} \mathrm{p}<0$. Source: Authors' calculations.

group whereas secondary education is most significant for high income at $10 \%$ level and less significant at 5\% level for upper middle income and low-income groups. Note that for tertiary education in the high-income countries in SSA, data does not allow for any tangible conclusion on its effect on economic growth because the variable is automatically dropped out of the regression perhaps due to insufficient data points. Overall, the role of education on per capita GDP is confirmed.

\section{Concluding Remarks and Emerging Policy Issues}

In this study, we extend an endogenous growth framework based on the augmented Solow as [9] to measure gender-specific and education level enrolment impacts on economic growth. We employ GMM coupled with sensitivity analysis to measure the growth effects of male and female primary, secondary and tertiary enrolment. We offer two important findings from the recent evidence on 
the impact of education on economic growth in Sub-Saharan Africa. First, we find that the greatest contribution to growth therefore is observed for secondary school investment followed by primary and tertiary education. Furthermore, compared to some of the existing cross-country findings with level-specific data, which are found insignificant growth impacts from tertiary education, our gender-disaggregated level-specific estimates are much more robust, showing that tertiary education has a significant positive impact on economic growth, although the magnitude is less in relation with other levels. Second, we observe a gender effect, wherein the growth effects of female enrolment being consistently higher than that of their male counterparts at all levels of education. This is a departure from other recent evidence on Asia.

In this regard, this gender effect may have important policy consequences. From theory, labor is compensated based on it abilities and skills. Thus, the productivity differential between men and women will serve to engender the increased participation of the girl child in education. As the vast literature in development economics on the impact of educating women, this finding is expected to result in those attendant positive consequences on socio-economic transformation of the continent. As such, policies to support in female education ought to be pursued. The issue focused on in the UNESCO Report by Chris Colclough, devoted to the effects of female education via Education for All, and is therefore very important particularly for SSA. The need for basic education in Africa is hence critical, if countries are to achieve sustainable growth.

In addition to enrolment, some of the control variables used are also found to have robust growth effects. Of these control variables, private domestic investment has the largest growth effect, with the rest of other variables being insignificant and in some models, yielding unexpected signs. Therefore, reducing the cost of credit would be important pro-growth policies in these economies, away from the common expectation that growth will come from out through foreign direct investment.

Additional empirical work on estimating the growth effects of education needs to address the issues of quality and level dependent skills acquisition as a way of demonstrating how such skills impact on growth. An important note is that we appreciate the difficulties of estimating the determinants of economic growth using country level data, either cross-sectional data or panel data as highlighted in [87]. Therefore we need to understand the results within these limitations.

\section{Conflicts of Interest}

The authors declare no conflicts of interest regarding the publication of this paper.

\section{References}

[1] Hanushek, E.A. (2013) Economic Growth in Developing Countries: The Role of Human Capital. Economics of Education Review, 37, 204-212. 
https://doi.org/10.1016/j.econedurev.2013.04.005

[2] Glewwe, P., Maiga, E. and Zheng, H.C. (2014) The Contribution of Education to Economic Growth: A Review of the Evidence, with Special Attention and an Application to Sub-Saharan Africa. World Development, 59, 379-393.

https://doi.org/10.1016/j.worlddev.2014.01.021

[3] World Bank (2012) World Development Indicators 2012. Washington DC.

[4] Aghion, P., Boustan, L., Hoxby, C. and Vandenbussche, J. (2009) The Causal Impact of Education on Economic Growth: Evidence from U.S. Harvard University, Mimeo.

[5] Lucas, E. (1988) On the Mechanics of Economic Development. Journal of Monetary Economics, 22, 3-42. https://doi.org/10.1016/0304-3932(88)90168-7

[6] Romer, P. (1990) Endogenous Technological Change. Journal of Political Economy, 98, 71-102. https://doi.org/10.1086/261725

[7] Barro, R.J. (1991) Economic Growth in a Cross Section of Countries. The Quarterly Journal of Economics, 106, 407-443. https://doi.org/10.2307/2937943

[8] Barro, R. and Lee, J.W. (1994) Sources of Economic Growth. Carnegie-Rochester Conference Series on Public Policy, 40, 1-46.

https://doi.org/10.1016/0167-2231(94)90002-7

[9] Mankiw, N.G., Romer, D. and Weil, D.N. (1992) A Contribution to the Empirics of Economic Growth. Quarterly Journal of Economics, 107, 407-437. https://doi.org/10.2307/2118477

[10] Solow, R. (1956) A Contribution to the Theory of Economic Growth. The Quarterly Journal of Economics, 70, 65-94. https://doi.org/10.2307/1884513

[11] Pegkas, P. (2014) The Link between Educational Levels and Economic Growth: A Neoclassical Approach for the Case of Greece. International Journal of Applied Economics, 11, 38-54.

[12] Hanushek, E.A., Schwerdt, G., Woessmann, L. and Zhang, L. (2017) General Education, Vocational Education, and Labor-Market Outcomes over the Lifecycle. Journal of Human Resources, 52, 48-87. https://doi.org/10.3368/jhr.52.1.0415-7074R

[13] Jalil, A. and Idrees, M. (2013) Modelling the Impact of Education on the Economic Growth: Evidence from Aggregated and Disaggregated Time Series Data of Pakistan. Economic Modelling, 31, 383-388. https://doi.org/10.1016/j.econmod.2012.11.035

[14] Scherer, F. and Hue, K. (1992) Top Managers Education and R\&D Investment. Research Policy, 21, 507-511. https://doi.org/10.1016/0048-7333(92)90007-Q

[15] Sapir, A., et al. (2004) An Agenda for a Growing Europe. Oxford University Press, Oxford. https://doi.org/10.1093/0199271488.001.0001

[16] Glick, P. and Sahn, D.E (2000) Schooling of Girls and Boys in a West African Country: The Effects of Parental Education, Income, and Household Structure. Economics of Education Review, 19, 63-87. https://doi.org/10.1016/S0272-7757(99)00029-1

[17] Lincove, J.A. (2009) Determinants of Schooling for Boys and Girls in Nigeria under a Policy of Free Primary Education. Economics of Education Review, 28, 474-484. https://doi.org/10.1016/j.econedurev.2008.10.001

[18] Byrd, M.W. (2012) Education, Economic Growth, and Social Stability: Why the Three Are Inseparable. https://apcss.org/wp-content/uploads/2012/09/Chapter8.pdf

[19] Krueger, A. and Lindahl, M. (2001) Education for Growth: Why and for Whom? Journal of Economic Literature, 39, 1101-1136. https://doi.org/10.1257/jel.39.4.1101 
[20] Fink, G. and Peet, E. (2014) Returns to Education in Low and Middle-Income Countries: Evidence from the Living Standards and Measurement Surveys. Program on the Global Demography of Aging at Harvard University Pgda Working Paper No. 120.

[21] Benos, N. and Zotou, S. (2014) Education and Economic Growth: A Meta-Regression Analysis. World Development, 64, 669-689. https://doi.org/10.1016/j.worlddev.2014.06.034

[22] Loom, D.E., Canning, D. and Jamison, D.T. (2004) Health, Wealth and Welfare. Finance and Development, 41, 10-15.

[23] Miguel, E. and Kremer, M. (2004) Worms: Identifying Impacts on Education and Health in the Presence of Treatment Externalities. Econometrica, 72, 159-217. https://doi.org/10.1111/j.1468-0262.2004.00481.x

[24] Bundy, D. (2005) School Health and Nutrition: Policy and Programs. Food and Nutrition Bulletin, 26, S186-S192. https://doi.org/10.1177/15648265050262S209

[25] WHO (2005) Deworming for Health and Development: Report of the Third Global Meeting of the Partners for Parasite Control. Geneva, 29-30 November 2004.

[26] Vogl, T. (2012) Height, Skills, and Labour Market Outcomes in Mexico. NBER Work. Pap. 18318.

[27] Barro, R.J. and Lee, J.W. (2013) A New Data Set of Educational Attainment in the World, 1950-2010. Journal of Development Economics, 104, 184-198. https://doi.org/10.1016/j.jdeveco.2012.10.001

[28] Psacharopoulos, G. and Woodhall, M. (1985) Education for Development: An Analysis of Investment Choices. Oxford University Press, New York.

[29] Suhrcke, M., McKee, M., Arce, R.S., Tsolova, S. and Mortensen, J. (2005) The Contribution of Health to the Economy in the European Union. European Commission. https://ec.europa.eu/health/archive/ph_overview/documents/health_economy_en.p df

[30] Winthrop, R. and McGivney, E. (2015) Why Wait 100 Years? Bridging the Gap in Global Education. The Brookings Institution, June 2015.

https://www.brookings.edu/research/why-wait-100-years-bridging-the-gap-in-globa l-education/

[31] Varghese, N.V. (2013) Governance Reforms in African Higher Education: The Missing Link. Chronicle of African Higher Education, Centre for International Higher Education, Boston, Boston College, No. 3, March 2013.

[32] Hassan, S. and Ahmed, H. (2011) Education's Contribution to the Economic Growth of Sub-Saharan Africa. Southwestern Economic Review, 35, 174-190.

[33] Knowles, S., Lorgelly, P. and Dorian, O. (2002) Are Educational Gender Gaps a Brake on Economic Development? Some Cross-Country Empirical Evidence. $O_{X-}$ ford Economic Papers, 54, 118-149. https://doi.org/10.1093/oep/54.1.118

[34] Klasen, S. (2002) Low Schooling for Girls, Slower Growth for All? Cross Country Evidence on the Effect of Gender Inequality in Education on Economic Development. World Bank Economic Review, 16, 345-373. https://doi.org/10.1093/wber/lhf004

[35] Hassan, G. and Cooray, A. (2015) Effects of Male and Female Education on Economic Growth: Some Evidence from Asia, Journal of Asian Economics, 36, 97-109. https://doi.org/10.1016/j.asieco.2014.09.001

[36] Schultz, T.P. (2002) Wage Gains Associated with Height as a Form of Health Human Capital. American Economic Review, 92, 349-353. 
https://doi.org/10.1257/000282802320191598

[37] Colclough, C., (2003) Achievement Schooling for All in Africa: Commitment Aldershot, Ashgate.

[38] Earle, D. (2010) Tertiary Education, Skills and Productivity, Tertiary Education Occasional Paper 2010/01. Ministry of Education, Wellington.

[39] Bloom, D.E., Canning, D., Chan, K.J. and Luca, D.L. (2014) Higher Education and Economic Growth in Africa. International Journal of African Higher Education, 1, 22-57. https://doi.org/10.6017/ijahe.v1i1.5643

[40] Shaihani, M., Harisb, A., Ismaila, N. and Saida. R. (2011) Long-Run and Short-Run Effects on Education Levels: Case in Malaysia. International Journal of Economic Research, 2, 77-87.

[41] Appiah, E.N. and McMahon, W. (2002) The Social Outcomes of Education and Feedbacks on Growth in Africa. Journal of Development Studies, 38, 27-68.

https://doi.org/10.1080/00220380412331322411

[42] Agiomirgianaskis, G., Asterious, D. and Monastiriotis, V. (2002) Human Capital and Economic Growth Revisited: A Dynamic Panel Data Study. Journal of International Advances in Economic Research, 8, 177-187. https://doi.org/10.1007/BF02297955

[43] Voon, J.P. (2001) Measuring Social Returns to Higher Education Investment in Hong Kong: Production Function Approach. Economics of Education Review, 20, 503-510. https://doi.org/10.1016/S0272-7757(00)00021-2

[44] Asteriou, D. and Agiomirgianakis, G. (2001) Human Capital and Economic Growth, Time Series Evidence from Greece. Journal of Policy Modeling, 23, 481-489. https://doi.org/10.1016/S0161-8938(01)00054-0

[45] Abbas, Q. (2001) Endogenous Growth and Human Capital: A Comparative Study of Pakistan and Sri Lanka. The Pakistan Development Review, 40, 987-1007. https://doi.org/10.30541/v40i4IIpp.987-1007

[46] Villa, S. (2005) Determinants of Growth in Italy. A Time Series Analysis. Working Paper, University of Foggia, Italy.

[47] Lin, T. (2006) Alternative Measure for Education Variable in an Empirical Economic Growth Model: Is Primary Education Less Important? Economics Bulletin, 15, 1-6.

[48] Gyimah-Brempong, K., Paddison, O. and Mitiku, W. (2006) Higher Education and Economic Growth in Africa. Journal of Development Studies, 42, 509-529. https://doi.org/10.1080/00220380600576490

[49] Chi, W. (2008) The Role of Human Capital in China's Economic Development: Review and New Evidence. China Economic Review, 19, 421-436. https://doi.org/10.1016/j.chieco.2007.12.001

[50] Loening, J.L. (2005) Effects of Primary, Secondary and Tertiary Education on Economic Growth. World Bank Policy Research Working Paper, 3610.

[51] Seebens, H. and Wobst, P. (2003) The Impact of Increased School Enrollment on Economic Growth in Tanzania. Center for Development Research, Bonn.

[52] Chou, C.P. (2003) The Great Experiment of Taiwanese Education: 1987-2003. Psychology Publishing, Taipei.

[53] Razzak, W.A. and Timmins, J. (2010) Education and Labour Productivity in New Zealand. Applied Economic Letters, 17, 169-173. https://doi.org/10.1080/13504850701719942

[54] Hanif, N. and Arshed, N. (2016) Relationship between School Education and Eco- 
nomic Growth: SAARC Countries. International Journal of Economics and Financial Issues, 6, 294-300.

[55] Neycheva, M. (2010) Does Public Expenditure on Education Matter for Growth in Europe? A Comparison between Old EU Member States and Post-Communist Economies. Post Communist Economies, 22, 141-164. https://doi.org/10.1080/14631371003740597

[56] Pegkas, P. and Constantinos T. (2017) Are There Separate Effects of Male and Female Higher Education on Economic Growth? Evidence from Greece. Journal of the Knowledge Economy, 8, 279-293. https://doi.org/10.1007/s13132-015-0286-Z

[57] Bils, M. and Klenow, P.J. (2000) Does Schooling Cause Growth? The American Economic Review, 90, 1160-1183. https://doi.org/10.1257/aer.90.5.1160

[58] Delgado, M.S., Henderson, D.J. and Parmenter, C.F. (2012) Does Education Matter for Economic Growth? IZA Discussion Paper No. 7089, December 2012.

[59] Barro R.J. (2001) Education and Economic Growth. In: Helliwell, J.F., Ed., The Contribution of Human and Social Capital to Sustained Economic Growth and Well-Being, Chap. 3, OECD, 14-41.

[60] Barro, R.J. (2001) Human Capital and Growth. American Economic Review, 91, 12-17. https://doi.org/10.1257/aer.91.2.12

[61] Leoning, J. (2005) Effects of Primary, Secondary and Tertiary Education on Economic Growth: Evidence from Guatemala. World Bank Policy Research Working Paper 3610, World Bank, Washington DC.

[62] Anderson, T.W. and Hsiao, C. (1981) Estimation of Dynamic Models with Error Components. Journal of the American Statistical Society, 76, 598-606. https://doi.org/10.1080/01621459.1981.10477691

[63] Arellano, M. and Bond, S. (1991) Some Tests of Specification for Panel Data: Monte Carlo Evidence and an Application to Employment Equations. The Review of Economic Studies, 58, 277-297. https://doi.org/10.2307/2297968

[64] Samimi, P. and Jenatabadi, H.S. (2014) Globalization and Economic Growth: Empirical Evidence on the Role of Complementarities. PLOS ONE, 9, e87824. https://doi.org/10.1371/journal.pone.0087824

[65] Sianesi, B. and Van Reenen, J. (2000) The Returns to Education: A Review of the Macro-Economic Literature. Centre for the Economics of Education Discussion Paper, 6. http://cee.lse.ac.uk/cee\%20dps/CEEDP06.pdf

[66] Dowrick, S. (2002) The Contribution of Innovation and Education to Economic Growth. Paper Presented at the Melbourne Institute Economic and Social Outlook Conference: Towards Opportunity and Prosperity, Melbourne Institute, Melbourne. http://melbourneinstitute.com/conf/prevconf/top2002/pdffiles/DowrickSteve2A.pdf

[67] Clément, R., Baker, S.C., and MacIntyre, P.D. (2003) Willingness to Communicate in a Second Language: The Effects of Context, Norms, and Vitality. Journal of Language and Social Psychology, 22, 190-209. https://doi.org/10.1177/0261927X03022002003

[68] Keller, K.R.I. (2006) Investment in Primary, Secondary and Higher Education and the Effects on Economic Growth. Contemporary Economic Policy, 24, 18-34. https://doi.org/10.1093/cep/byj012

[69] McMahon, W.W. (2002) Education and Development: Measuring the Social Benefits. Oxford University Press, Oxford and New York.

[70] McMahon, W.W. (2007) An Analysis of Education Externalities with Applications to Development in the Deep South. Contemporary Economic Policy, 23, 459-482. https://doi.org/10.1111/j.1465-7287.2007.00041.x 
[71] Choi, I. (2001) Unit Root Tests for Panel Data. Journal of International Money and Finance, 20, 249-272. https://doi.org/10.1016/S0261-5606(00)00048-6

[72] Aboagye, S. and Turkson, E.F. (2013) An Empirical Investigation of Per Capita Income Convergence Hypothesis in Sub-Saharan Africa. Department of Economics, University of Ghana, Legon-Accra.

[73] Winters, J.V. (2018) Do Higher College Graduation Rates Increase Local Education Levels? Papers in Regional Science, 97, 617-638. https://doi.org/10.1111/pirs.12258

[74] Psacharopoulos, G. and Patrinos, H.A. (2004) Returns to Investment in Education. A Further Update. Education Economics, 12, 111-134. https://doi.org/10.1080/0964529042000239140

[75] Barro, R.J. and Lee, J.-W. (1996) International Measures of Schooling Years and Schooling Quality. American Economic Review, 86, 218-223.

[76] McMahon, W.W. (1998) Education and Growth in East Asia. Economics of Education Review, 17, 159-172. https://doi.org/10.1016/S0272-7757(97)00050-2

[77] Pritchett, L. (2001) Where Has All the Education Gone? The World Bank Economic Review, 15, 367-391.

[78] Gyimah-Brempong, K., Paddison, O. and Mitiku, W. (2006) Higher Education and Economic Growth in Africa. Journal of Development Studies, 42, 509-529. https://doi.org/10.1080/00220380600576490

[79] Harman, G. and Harman, K. (2003) Institutional Mergers in Higher Education: Lessons from International Experience. Tertiary Education and Management, 9, 29-44. https://doi.org/10.1080/13583883.2003.9967091

[80] Schoors, K. and Van Der Tol, B. (2002) The Productivity Effect of Foreign Ownership on Domestic Firms in Hungary. EEA Venice Conference Paper.

[81] Lee, H.H. and Tan, H.B. (2006) Technology Transfer, FDI and Economic Growth in the ASEAN Region. Journal of the Asia Pacific Economy, 11, 394-410. https://doi.org/10.1080/13547860600923593

[82] Baharumshah, A.Z. and Almasaied, S.W. (2009) Foreign Direct Investment and Economic Growth in Malaysia: Interaction with Human Capital and Financial Deepening. Emerging Markets Finance and Trade, 45, 90-102. https://doi.org/10.2753/REE1540-496X450106

[83] Sarel, M. (1995) Nonlinear Effects of Inflation on Economic Growth. IMF Working Paper No. WP/95/56.

[84] Khan, M.S. and Senhadji, A.S. (2001) Threshold Effects in the Relationship between Inflation and Growth. Palgrave Macmillan Journals, 48, 1-21.

[85] Tobin, J. (1965) Money and Economic Growth. Econometrica, 33, 671-684. https://doi.org/10.2307/1910352

[86] Temple, J.R. (2000) Growth Regressions and What the Textbooks Don't Tell You. Bulletin of Economic Research, 52, 181-205. https://doi.org/10.1111/1467-8586.00103

[87] Durlauf, S.N., Johnson, P. and Temple, J. (2005) Growth Econometrics. In: Aghion, P. and Durlauf, S.N., Eds., Handbook of Economic Growth, North Holland, Amsterdam, 555-677. 